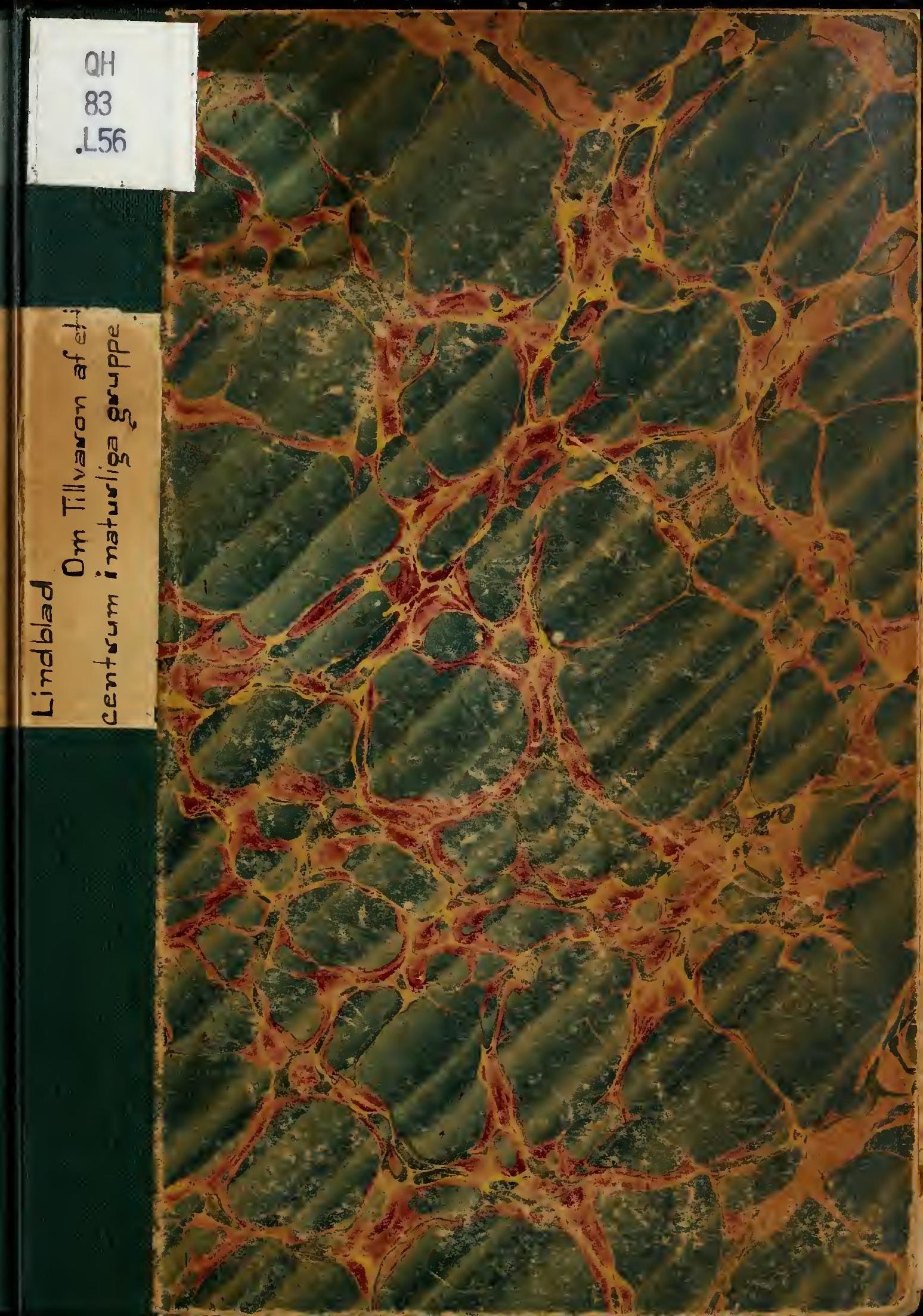




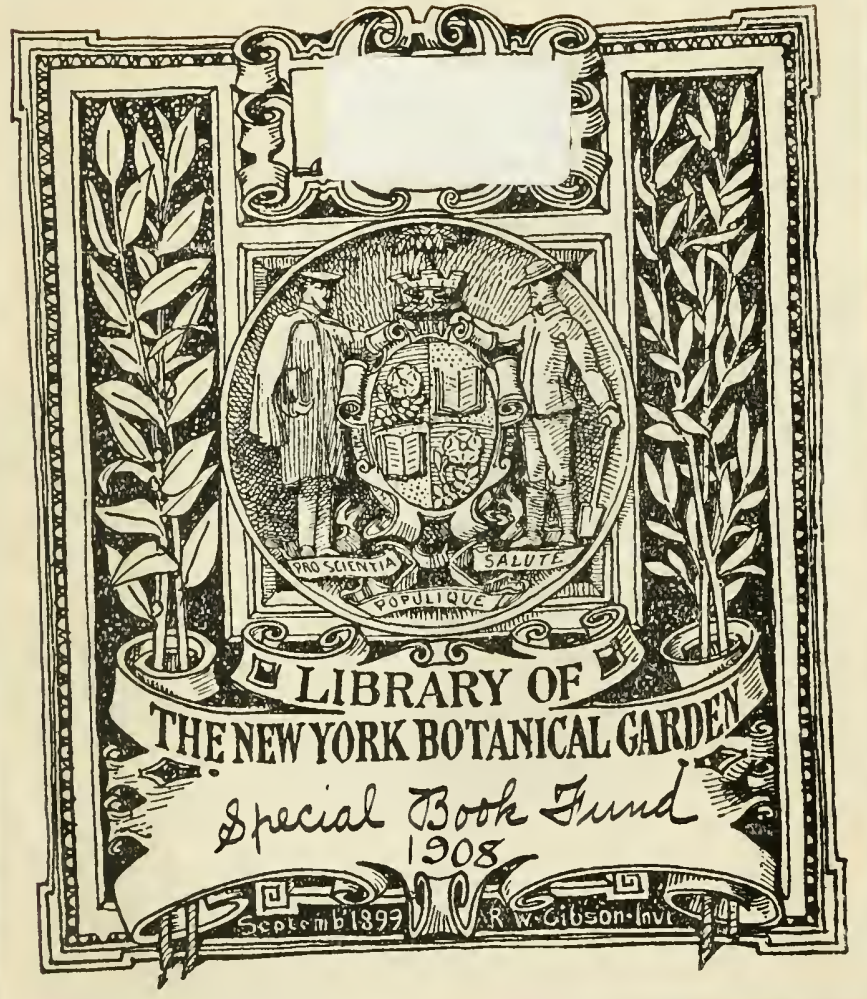


$0 \mathrm{~m}$

\section{Tillvaron af ett centrum i maturliga grupper såväl inom Djur- som Växt-verlden.}

Akademisk Afhandling,

som

med vidtberömda Hilosofiska Facultetens i Lund tillstånd

till offentlig granskning framställes

af

\section{Mag. MATTS ADOLF LINDBLAD,}

Jocent i Botanik vid Upsala Universitet,

Lördagen den 29 April 1857,

å Auditoriet N:o 1, kl. 9 f. m.

LIBRARY

NEW YORK

BOTANICAL

GARDEN.

Lu n d,

tryckt uti Berlingska Boktryckeriet,

1857. 


$$
\begin{aligned}
& Q H \\
& 83 \\
& . L 56
\end{aligned}
$$




\title{
Medicine Kandidaten
}

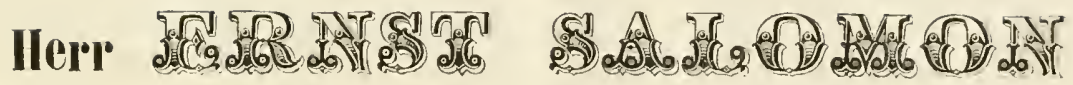

\author{
tillegrnas \\ såsom uttryck \\ af \\ en aldivg slocknande tacksambor \\ tessa blad
}

Finlatlaren. 

"Ut vero scientia in posterum magis maturet, quam amhitu crescal: in votis est."

Fries, S. Veg. Sc. p. 266.

Då Förf. för omliring tvenne år sedan var sysselsatt med utarbetiudet af en monografisk franställning af slägtet Lactarius (bland Hymenomyceterna) var den förnämsta uppgiften härvid - såsom viil äfven alltid $i$ dylika fall — att tydligt uppfalla den ifrågavarande gruppens såväl egendomligheter som förhållanden till sina samordnade.

En särdcles framstående egenskap, som för öfrigt blott förekommer hos lelt få, $\mathrm{i}$ andra hänseenden högst olika, svampar i Hymenomycelernas stora familj, gör Lactarierna redan vid den flygtigaste granskning mycket lätta alt skilja frân andra. I alla sina delar innehålla de nemligen ymnigt en mjöllilik, ïn färgad, än ofärgad, saft, som vid minsta yttre skada utsipprar.

I flera hänseenden komma Laclarierna deremot mycket nära slägtet Russula, men i hänseenden, hvarigenom åter dessa båda slägten mycket skilja sig från alla andra till samma familj hörande.

Först och främst genom en byggnad, till stor eller större del, af lilotrunda stora celler, omslingrade af ytterst fina fibriller. Alla öfriga Iymenomyceter ïro byggrla năstan uteslutande af långsträckta celler. En följd af deuna olikhet i byggnad är att delarna hos Lactarius och Russula lätt låta sig skiljas i hvad rigtning som helst, under det, hos flertalet af de öfriga, delarna lättare skiljas $\mathrm{i}$ strålrigtning hos hatten och $\mathrm{i}$ längdrigtning hos foten. I sammanhang med denna så att săga mer elementära eller enklare inre lyyggnad hos Lactarius och Russula står en klumpig yttre form, icke jemförlig med den lediga och lätta, som tillkommer så många an. dra bland Hymenomycetes. 
En annan egensliap, - i ett ancat hänseende, som äfven och isynnerhet los de köttiga svamparne visat sig vara af vigt - hvilken uteslutande funes hos Lactarius och Russula, är en viss aromatisl smak, än mild, än, och oftare, sticliande eller brännande, med olikheter som för tungan nästan endast förete en skillnad i grad.

Sporernas färg, hvilken bland svamparne är en egenskap, som visar sig i lı̈g grad beteclinande för angifvande af förvandtskapen, är hos båda dessa slägten lika: antingen hvit eller ockragul.

Genom dessa likheter, som dessa båda sligten med hvarandra förete, $\mathrm{i}$ båda förstnämnda hänseenden med uteslutande af andra, ådagalägges en den uärmaste förvandtskap, ehuru hufvudtyperna $\mathrm{i}$ form för dessa báda slägten icke obetydligt afvika från hvarandra. Deras ytterligheter förmedlas dock på ett utmärlit sätt genom ett inskiänktare antal till Russula hörande arter, livilka man knappt annat än genom frånvaron af mjöllisaft kan skilja från Luctarius.

Mycket egendomliga och med lıvarandra nära förvandta samt högst lätta att från andra skilja visa sig, på grund af hvad vi ofvan anfört, dessa båda slägten.

Utom genom sin mjölksaft, hvarom vi ofvan nämut, utmärker sig åter Lactarius ifrån Russula, hvad den inre byggnaden angår, genom tydliga långstrïckta kärl, enkla och grenade, hvilka i flera rilitningar genomkorsa dess inre, och sannolikt föra mjölksaften. Ios mảnga arter af Lactarius visa siğ derjemte på fotens yta, såsom normalt förel:ommande, små insänkningar med platt botten och skarpt angifven kant. Dylika fläckar hafva icke på nảgra andra svampar blifvit sedda. Ändtligen och till sist förckomma på en stor del arter af Lactarius på hattens ötre yta concentriska, mer eller mindre oliktärgade, teclningar i form af smala ringar, livilka man kallat zoner, firre eller flera till antalet; under det hos andra liöttiga svampar högst sällan sådana visa sig, och då aldriğ så utmärkta, som de förekomma hos de fullkomligare bland Lactarierna. 
En mïngd egendomligheter förete sig sålunda och erbjuda sig lätt för en uppmärlksam granskning, på grund af hvilka såvïl Lactariuts jemte det mycket nära förvandta slägtet Russula skilja sig från alla andra Irymenomycetes, (ännu mindre ega de förvandta $i$ någon annan familj af svamparnas klass), som slägtet Lactarius särsliildt ifrån slägtet Russula.

Långt svårare var att vinna ett tydligt begrepp om det förhållande hvari de stá till öfriga till samma farnilj hörande former, hvillas mångfald, lảngt tydligare för öfrigt än $i$ mânga andra grupper inom vïxtverlden, vid första anblicken visar sig ntgöras af högre och lägre former, i sammanhängande serier.

Till följd af sina på en gång många och utmärkta egendomligheter visade de sig stå mycket isolerade, och inga närmare förvandta kunde spåras. Det áterstod oss då blott att eftersöla deras aflägsnare - ty nảgra borde de väl sannolikt ega - jemte de förhállanden af mer eller mindre aflägsen likhet $i$ ett eller annat hänseende (analogie, sken), hvari de kunde stå till andra former. Vi ansågo oss dertill så mycket mer uppmanade, som detta förhållande ofta på mångfaldigt sätt, enligt allas erfarenhet, visat sig förefinnas inom alla kretsar i den organiska verlden, för att blott hålla oss vid denna.

Skillmaden emellan förvandtskap och likhet eller sken (affinitet och analogi), såsom allmänt bekant, torde vi ej behöfva närmare beröra.

Ehurı vår första uppgift var att söla vinna ett tydligt begrepp om den plats slägtet Lactarius intager ibland Hymenoinycetes, ansågo vi tjenligast, för lättande af vár uppgift, att först $i$ samma hänseende betrakta detta slägte gemensamt med Russula; sedan vi pả en gång funnit dem båda sins emellan särdeles nära förvandta och tillsammans lảngt skiljda från alla andra.

Den närmaste, sjelfmant sig tramställande, anmärkningen rörande dessa båda slägtens förvandtskaper med andra är, att de genom sina mycket väl utbildade lameller tillhöra den stora ordningen Agaricinci, samt att de tillhöra den stora mängd bland dessa, livilka ega lösare, köttig substans. Hos jemfö- 
relsevis ett fåtal inom denna ordning ïr substansen seg, läderartad eller till och med kork- eller trädartal. De förstnämnda af dessa äro ögonskenligen de fullkomligare.

Genom den afviliande byggnaden af lamelleruas inre lager, hvari Lactarius och Russula, i formelt hänseende, bland alla köttiga former af samma ordning kunna jemföras nästan endast med Cantharellerna, - hvilla, med sina föga utbildade lameller samt $\sin$ iffven egendomliga, med några af de $i$ hela familjen lägsta formerna till stor del likartade, substans, tydligen inom sin ordning intaga den lägsta platsen bland de köttartade svamparna - likasom genom sin egen, så att säga râare både form och substans visa sig dessil slägten uppenbarligen såsom äfven sjelfva lågt stâenile former, och man finner derföre lätt rigligheten af Fries' anordning, att ställa dessa slägten näst ofvan on Cantharellerna. Den stora mängden af öfriga löttiga Hymenomycetes - äfven alla de arter af Hygrophorus, lıvilka vi varit i tillfälle att undersöka, likasom Paxillus (Lepista) extenuatus - hafva en gemensam egenskap med afseende på detta inre lager i lamellen, hvarom vi ofvan talat. Detta lager (trama) är nemligen hos dessa med afseende på cellernas byggnad något olika substansen i hatten, hufvadsakligen med afseende på cellernas rilitning och läge till hvirrandra. Såson exempel på detta fürhållande hänvisa vi till den teckning af en del af tramat samt af hatlens substans hos Agar. brumalis, hvillien vi (Tab. VII) meddelat.

Några af de öfriga köttiga, lıvilka i förhållande till sina närmaste samsliggtingar stå li̊gt, Coprinus tillika med Bolbitius, sakna trama, likason Paxillus (Tapinia). Isynnerhet hos Russula (Tab. VII) deremot, i flera arter hvilka vi granskat, och Cantharellus, det sednare slägtet med sina trubbiga och låga lameller, ser man cellernas byggnad och förhållanden i tramat vara alldeles lika med dem i hatten. Hos Lactarius synes detta förhållande variera; $i$ den teckning af tramat $\mathbf{m}$. $\mathbf{m}$. som vi meddelat af $L$. blennius (Tab. VII) äro sådana stora klotrunda celler, hvilka ymnigt och gruppvis förekomma $i$ hattens substans, mycket sparsamma. Hos andra arter (L. vellercus isynnerhet) hafva vi funnit denna skillnad mindre stor. 
Att sälla dylika former med "trama immutala" lågt, dertill vinner man, utom de grunder deras egna öfriga förhållanden lemna, elt utmärkt stöd genom granskning af de analoga formerna bland Polyporei, der de, som tydligast hafva trama immututa, uppenbarligen stâ myclet låğt. Allt dessa göra det är på grund af derıs förhållanden af sig sjelft tydligare in fallet är vid en omedelbar granslining af Lactarius och Russula, rörande dessas słälluing. Dessa sisınamnda slägten hafva nemligen ett slien af' att stà temligen, någon liunde säga mycket, lıögt, emedan bland dem blott högst sällan former förekomma, hvilka hafva foten $\mathrm{i}$ sidoriktning med hatten, eller som växa på träd; bland dem förekomma aldrig sådana, som salina fot: under det i slïgtet Agaricus, hvillet, med Amanita $\mathrm{i}$ spetsen, författarne allmänt sätta högst, dylika former och förhållandeı som de sistnïmnda ofta förekomma. - Bland de Polyporei deremot, hvilla ega "trana immufata" som tydligast: Trametes, Diedalea, Hexagona, om man ens kan tala om trama hos den sistnämnda, förekomma aldrig former som ens hafva fot, under det sådana icke sïllan förckomma i de slägten, som stả Boletus närmare: Polyporus och Polysticlus.

Att Lactarierna jemte Russulce, på grund af ofvannämnda förhållande, att högst sällan former med foten i sidorikining med hatten m. m. lilaad dem förekomma, sliulle, i strid med hvad alla öfriga förut nämuda förhållanden föranleda alt antaga, st:i särdeles lıögt, det visar sigg icke antingligt äfven af det skälet, att då skulle öfriga slïgten, om hvilka samma sak gäller, och detta i ïnnu mera utmärkt gुrad, sâsom Cortinarius, Hygrophorus, Gomphidius, på samma grund intaga en temligen hög plats. Men livad den yttre formen angår äro alla dessa slägten analoga med just sådana afdelningar $i$ det stora, alla de nyssnïmuda tillsammans $i$ formernas mångfald långt öfverträffande slägtet Agaricus, hvilka sjelfiva (Tricholoma, Clitocybe) omedelbart sammanhänga med dem, hvillaa såväl hafva foten i sned rilitning, som genom dessa med dem som sakna fot. ¿ andra sidan finnas med dessa lika så omfattande afdelningar inom slägtet Agaricus (Collybia, Mycena m. fl.) lıvilka allt mer närma sig de alltid såsom lıögst stảende ansedda 
Amanite, och lıvilka jemte dessa sistuämnda och deras förvandta lika sả litet som isynnerhet Laetarius och Ihussula bland sig ega forner med sned fot eller öfverhufvud mindre regelıässiga former, utan i detta hänseende i allmänhet förete just motsalsen.

Frân hval synponkt vi derfüre in betraktade förhållandena, funno vi alltid skäil ansluta oss till Fries' anordning att stialla Luctarius och Russula bland de aldra lïgsta formerna af de költiga Agaricines.

Nära förvandia till dem funno vi, såsom vi ofvan nämnt, inga. Med Cortinarius, Gomplielius och Hygrophorus egde de det gemensamt att nästan uteslutande växa på marken och ej hafva några sneda former, ehuru Lactarius och Russula dock antydde en lägre plats just genom tillvaron af några (ehuru dessa blott högst få) sảdana ibland sig. Alla dessa slägten visade sig ock ega det gemensamt, att alla de tormer de under sig sammanfatta, haf'va nâgot tungt, så att säga groflemmailt, $i$ sitt utseende, och detta just $i$ den ordning $i$ hvilken vi här uppräknat dem och de af Fries blifvit anordnade. Från alla dessa nämnda afvila dock Lactarius och Russula, redan vid en flygtig undersökning, genom den sprödhet, hvarom vi ofvan talat. Alla de andra låta, så vïil hvad hatten angår som foten, mer eller mindre liitt upprispa sig i långa fibrer, men något sålant lyckas ej med Lactarius och Rissula. Vi hade hittills blott bland de köttiga Agarieinci, hvarest förvandta till Lactarius och Russula heldst varit att förvänta, sölit sådana till dem. Bland de sega och trädartade af samma ordning funno vi heller inga. Vi vände dả vảr blick till den öfriga delen af Hymenomycetes, hvilka skulle kunna kallas dessas lïgre hemispher. Iclie utan betydlig öfverraslining funno vi då att flera af de båla nästföljande ordningarnas (Polyporei och IIy(uei) högsta former med våra båda slägten egde gemensam den sprödhet $\mathrm{i}$ brottet och den frånvaro af fibrös byggnad, just isynnerhet hvad foten angår, hvilken vi förgäfves sölit bland andra Agaricinei. Väl äro dessa högre former (af slägtena Boletus och Hydnum) ei byggda af dylika klotrunda celler, som Lactarius och Russula till så stor del 
äro; men i ofvan nämnda egenskaper erbjuda de till dessa slägten en anknytningspunlit, som vi ingenslädes annars funnit, huru vidt sliilja de än från dem äro i hymeniets form. För öfrigt funno vi i Hymenomyceternas hela grupp inga, som med Laclarius, Russula, ifrågavarande Bolcti och några Hydna delade nyssnämnde egenslap, hvilken redan vid en flygtig granskning förekommer temligen utmärkt. Möjligen torde dock nagra Paxilli, heldst bland afdelningen Lepista, dela samma egenslap. För öfrigt öfverensstämma dessa med de fyra nyssnämnda $\mathrm{i}$ formernas, så alt säga, simpelhet.

Vi voro öfverraskade att sålunda finna de båda näimnda slägtena, Boletus och IIyduum, hvilka livar för sig - det sednare just med sina liöttiga arter; ty det eger äfven och flera trädartade - obestridligen utgöra höjdpunkterna i de ordningar de tillhöra, derjemte nära sammanhöra med Lactarius och IRussula, hvilka vi funnit stå mycket lagt i hela filmiljens högsta ordning: slägten för öfrigt hos hvilka vi antecknat så många utmärkande egendomligheler.

Det nya i saken öppnade för oss en ny utșigt till uppfattande af förvandtskaperna i allmänhet bland IIymenomycetes, och manade oss till vidare sorgfällig granslining.

Vid betraktandet härunder, hurusom Lactarierna å ena sidan stå lågt ned $\mathrm{i}$ den omfattande ordningen Agaricinei, hvilken innehåller mera än halfva antalet lianda arter $\mathrm{i}$ hela familjen; vidare hurusom de visa största förvandtskap just till höjdpunkterna i de näist efter följande lägre ordningarne; hurusom dessa ordningar såväl sins cmellan, som (genom äfven andra, lïgre, former in Boleti), med Agaricinei utgöra en fast enhet, och hurusom derjemte Lactarierna, såsom vi sett, ntảjorde den utmärlkaste länlien, hvarmed de lägre ordningarne voro förenade med Agaricinei, och hvad mängden af arter ofvan och nedan om sig angăr, såsom vi ofvan antydt, befunnos stå ungefärligen i midten af det licla: vid betraktandet af dessa förhållanden, och då vi derjemte kommo att fàsta vår uppmärlisamhet derpå, hurusom Lactarierna, sådana de voro, i sig förenade tvenne karakterer, som bland Hymenomycetes annars bruka utesluta hvarandra: å ena sidan köttartad sub- 
stans, såsom de högre svamparna: à den andra zonerad hatt, såsom de lägre, trïidartade; då träffade oss blixtlikt och oemotståndligt den tanken, att Lactarierna måste tillhöra en central grupp och derjemte sjelfva utgüra just ett centrum bland IIymenomycetes: en besiimning emellertid, åt hvilken, så specificerad, vi dittills aldrig ens lyftat eller vågat lyfta vår tanke.

Vår öfverraslining var stor och liflig, heldst i betraktande af den mangfald af olilia och vidt skiljula former som familjen Hymenomycetes omfattar, och för hvillien Lactarierna nu sluulle utgöra ett verkligt, tydligt utprägladt, centrum; och vi tvekade ett ögonblick, om vi sluble fullfölja den idé, som tett sig för vår syn, eller fly den, sisom en villande och farligg hägring. Men vårt uppsàt var dock icke ondt och vi hade icke förmätet satt oss till någon slags uppgift att $i$ naturen söla motsvarighet till några slags vảra enskilda lystenheter. Hvarföre sliulle vi trukta? Vore det icke snarare orätt att sluta ögat till? Kansle var häri en gnista af det. sanningens ljus som, i lyckliga ögonblick, lommer en ärlig forslining till mötes? Vi fullföljje derföre denna idé, hvillen, g’enom den lögst speciela bestämning den innebar, så vidt vi hafva oss bèkant, var väsendtligen ny.

Om centra inom grupper i naturen tala emellertid många författare, Fries mest af alla med hvilka vi gjort bekantskap, hvilken dock ofta fattar denna bestämning $i$ nảgon annan mening än den vi vilja gifva den, ehuru å andra sidan $\mathrm{i}$ det enskilda vi ofta sammanträffa med honom i den konkreta bestämningen, såsom rörande Trichogastres såsom centrum bland Gasteromycetes o. a.

Endlicher talar om Liljorna som centrum bland Monocotyledonece *), Anacardiacea såsom centrum bland Terebinthinece $\left.{ }^{\star *}\right)$ o. s. v.

Tulasne bestämmer Phragmidiacei till centrum bland Uredinei $\left.i^{\star \star \star}\right)$.

Vi torde ej behöfva anföra flera författare.

-) Enchir. Mnt. p. 84.

*) L. c. p. 599 .

₹**) Ands. Årber. i Bot. 1835 och 1854 p. 13. 
Ingen har emellertid, oss veterligen, fullföljt idén om ett centrum, med att sölia det inom ett, jemfördt med kretsen i sin helhet, så litet omfảng, som vi, under vår granskning af slägtet Lactarii ställning inom familjen IIyncnomycetes, af omstandigheterna föranleddes alt göra.

Med myclien försiglighet och noggrannhet, samt alltid blott med föresats att söka sanningen, gransliade vi nu åter slägtet Lacturius och dess förhållanden till öfriga IIymenomycetes, men nu $\mathrm{i}$ en vida mer omfatlande mening ïn förut, och särskildt med uppgiti att tillse huruvida dessa fürhållanden sammanstïmde med de fordringar vi ansågo innebäras i bestämuingen "centrum."

Då man inviander ordet centrum, anse vi först deraf följa, att den bestïmning man dervid lïister, ej lian fả strida emot den $\mathrm{i}$ mathematiken, hvarifrån begreppet närmast är lånadt, gifna: att hvad som sa benïmnes shall ligga $i$ midten af en lirets, denna må föröfrigt vara af flerahanda form, blott den förtjenar namnet lirets. Derefter, och då fråga ïr om att öfverflytta detta begrepp på sådana sammanfättningar, inom den beskrifvande och systematiserande naturalhistorien, af med hvarandra företrïdesvis förvandta former, hvilka man der lïnge varit van benäimna kretsar; då tro vi den ofvan gifna negaliva bestämningen innebära, att den bland mångfalden at förevarande former, hvillien man gifver namnet centrum, måste vara såväl sliljul, lika långt firån de högsta och de lïgsta, som företrädesvis det föreningsband, hvarigenom de högre $i$ allmänhet och de ligre med hvarandra sammanhöra. Vi säga högre och lïgre, emedan i naturalhistorien alltid, ifven då man anvïnder bilden "lirets" för en samling med hvarandra nära sammanliörande former, man, rörande de enskilda formernas förhållanden till hrarandra, gör sliillnad emellan högre och liigre.

Rörande nu de förhållanden, hvilla för slïgtet Lactarius ïro egendomliga och hvilka, till antalet jemförelsevis många, med dem delas af inga andra Hymenomycetes än, men detta dock till en stor del, af slägtet Rnssula, hafva vi ofvan talat.

Bland egendomigheterna hos dessa bảda slägten, ïr det äanu tvenne, hvilka büra uppmärksammas. Först formen af 
deras sporer, hvilken ïr klotrund och taggig, under det öfriga Hymenomyceters sporer iro aflånga och slïta; ehuru medgifvas måste, att många former finnas, hvilkas sporer ej blifvit noggrannare undersökta, isynnerhet sådana, som blifvit hemförda frản tropiska länder. Af intresse är det deremot erinra, att i stället hos många Gresteromycetes förckomma sporer, hvilka på en gång ïro kilotrunda och taggiga, såsom hos Lactarius och Russuda.

Derefter förtjenar ock anmärkas, alt bland köttartade svampar det företrïidesvis är arter af slägtena Lactarius och Russula, hvilka lıysa andra, mindre, svampar såsom parasiter, såsom Nyctalis prarasilica sant större delen arter af slïgtet IIypocrea, för hvilka man ej liänner annan station än arter af Lactarius eller Russula.

Hvad nu âter Lactarierna särskildt angår: i så många förhållanden der vi kunde finna någon likhet med öfriga IIymenomycetcs, gransliade vi dem och jemförde.

Dessa förhållanden voro: gestaltens resning (forma hymenophori) och i följd deraf lamellernas ställning; fotens iure byggnad; "velum universale sant partiale" (tvenne bland IIymenomycetes särdeles vigtiga bestämningar), samt sporernas färg.

I alla dlessa förhållanden, hvilka, jemte några af dem, der Lactarierna tör öfrigt visade sig alldeles egendomliga, vi tro vara de väsendtligaste at hittills beaklade, funno vi Lacetaricrua "göra en "ratio media" för de förhâllanden, som bland Hymenomycetes i mycket mångfaldiga skiftningar förelomma, eller, med andra ord, tydligen uttryela ett centralt förhållande med afseende å alla de andra.

En utförligare framstïllning af vára undersökningar härom imnehâlles $\mathrm{i}$ inledningen till vår "Monographia Lactarivruim Sueciæ."

Såsom vi ofvan antydt, var det derjemte tvenne förhállanden, i lıvilka Lactarierna närmast liunde jemföras blott med den högre atdelningen blaud Hymenomyceles, nemligen den liöttartade substansen samt hymenii form af lameller; tvenne åter var det ock, $i$ hvilka de närmast kunde jemföras blott med den lägre: tramats besliaffenliet samt närvaron af 
zoner på hatten. Detta förbâllande af förening af motsatser i en enhet var, till allt det öfriga, det bindande beviset för sanningen af den idé, vi vågat uppfilla och granslat. Närvaron isynnerhet af lysande zoner på en liöttartad hall - det mest ögonskenliga nttrycket af demna motsatsernas förening - ansågo vi ocli såsom det bekrifiltande inseglet å verliligheten af della ifven $i$ andra hänsecuden tillvarande förhảllande, och såsom det ögonskenligga uttryeket af Lactariernas centrala stälning i Hymenomyceternas familj; liksom det ock var detla förhållande, hvars belraktande först hos oss väclite tanlien derpå, att de båda hemispharerna, für att så säga den högre och den lïgre - verliligen kunde vara representerade $i$ en enda punkt. Vi voro nu ofvertygade derom, att ett sådant förhållande eger rum.

Vi funno derefter, vid närmare granslining, aft de slïgten, mest af mindre omfang (Paxillus, Gomphilius, Stylobates, Cantharellus, Nyctalis, Arhenia), hvilka jemte Lactarius och Rinssula af Fries äro ställda lägre än alla de öfriga költartade, också med allt skïil hafva fåt denna plats; men ocksả, ehuru dessa slägten, såväil frân hvarandra som från Lactarius och Russula äro lângt mera skiljda, än slägten $i$ de flesta andra grupper äro, alt de dock jente dem, alla tillsammans, ulgöra en naturlig grupp. De ega ej blott det gemensamt, att lït kunna skiljas frản öfriga Agaricinei, utan en gemensam hufvudtyp förenar ïfven dem alla.

Ilärvid är emellertid ett förlıållande särdeles anmärkningssvïrdt, det nemligen, att de af dessa slägten, hvilla till antalet eller de fọmers mångfald, som under hvart och ett af dem hörer, äro nảgot mera omfattande, nemligen Hygrophorus, Lactarins och Rinssula, i ett af́seende förhảlla sig alldeles omvändt, $\mathrm{i}$ jemförelse med slägten al högre ordning. Sådana högre slïgten (eller grupper, itall man anser sig böra kalla Tricholoma, Clitocybe m. fl. för subgenera) skilja sig nemligen med de fulliomligare bland sina former langt frản livarandra, under det de med de lägre nära, ofta mycket nära, beröra hvarandra. Det ïr beliant, att sâ $i$ allmänhet är förhâllandet med naturliga grupper inom den organislia verlden, hvilla i 
något hänseende beröra hvarandra, att det är nästan endast med de lägsta lormerna, som de inbördes komma livarandra nära. Vi torde blolt behöfva erinra om förhållandet i delta afseende emellan viixter och djus.

Det är deremot i sina högsta former, som ifrågavarande slägten med hvarandra ega den största liliheten, $i$ sina lägsta den mindsta. - Att deremot afdelningarna Limacium bland Hygrophori, Piperites bland Lactarii, samt Compacte bland Russulce, hvar i sitt slïgte, äro de fullkomligaste, det, visar sig lätt redan vid en flygtig granslining af dessa slägtens kretsar i sin helhet. Det är i sarnma slïgtens öfriga aldelningar, som de till storlek mindre och till formen mindre regelbundna arterna förekomma. I samma slägtens högre aflelningar uttrycka alla arterna den typ af pá midten nedtryclit hatt, samt på foten långt nedlöpande lameller, livillien torde vara renast utbildad hos gruppen Clitocybe, inom det omfattande sligitet Agaricus. Samma typ är det ock, som ligger till grund för de högre formerna af de öfriga, mindre, sliigtena, hvilka alla vi anse med nyssnämnda trenne sammanhöra $i$ en naturlig krets, hvilken vi benämnt: "den centrala liretses i IIymenomyceternas fanilj." Tvenne af dessa små sligten, Gómphidius och Stylobates - eller bältre trenne, ty vi tvaka ej antaga afdelningen Lepista bland Paxilli för eget slïgte - äro blott liända i nảgra, helt fá, arler, hivillia mycket rent återgifva nyssnämnda typ. Trenne af de öfriga, $\mathrm{i}$ formrikedom något mera omfattande, Paxillus (Tapinia), Cantharellus och Arrhenia förete både i sina hügsta och liigsta former med hvarandra myclien analogi: de bögsia uttryckinde samma nyss anförda typ; de liigsta deremot airo former utan fot med hängande hait. Sistnaimnda furm är dock hos Puxilhs funnen blott sảsom varietet af dess lïgsta art, af Cantharellus och Arrhenia deremot i flera af dessas. Dessa tre sma slägten ligga ock alla $i$ ulkanterna, för alt sá sïga, af den lirets vi uppstïllt; det förstnämnda svårligen inlagande annan plats $\mathrm{i}$ kretsen än närmast till de öfrigă, högre, Agaricinei; de båda andra stå allıför tydlight på gränsenen till de lägsta $\mathrm{i}$ samma ordning. 
De typer åter, hvillia de lïgsta arterna af de i liretsens midt stående sliggteni, Hygrophorus, Lactarius och Russula, uttrycka, öfverraslia genom sin tillvaro i samma sliigten, emedan de, såsom typer helraklade, i allmänhet inom IIymenomyceternas familj intaga en plats, mer eller mindre langt öfver den, som är de högsta arternas i samma slägten. Sálunda uttrycka, då afsecnde fäistes blott pả formen, ejj pá substansen, inom sill slighte IIygrophorus couicus och spadiceus på det mest tydliga sätt - delvis ïfven II. muiceus, obrusseus jemte de ötriga i samma afdelning - den typ, som företrädesvis tillhör subgenus Mycena, jemte dess analoga subgenera, bland Agarici; bland Lactarii, L. liyniotus, med sina förvandta, Iypen für en Collybiat och till sist bland Renssula erinrar flerialet genom sina lamellers form, i förening med en i kanten ofta strimmad hatt, på eft öfverraskande sätt om den typ, som för öfrigt uteslutande tillbör de högst af alla Hymenomycetes sticnde Amaniterna.

Det torde förtjena bemärkas, då, såsom vi ofvan anfört, ordningsföljden af dessa trenne slägten, IIygrophorus, Lactarius oeh Russula, i systematislit hïnseende, icke lian vara någon annan in den, hvari vi här anfört dem, och så, att Iygrophori måste stiillas högst: alt de typer, som samma slïgtens lägre former uttryclia, uppträda i omviind ordning, jemförd med slïgtenas egen; så, att hos de lïgst staiende, Hygrophori, uppträder den lïgsta af nyss näimnda, med Clitocybe-typen olika - da man jemför dessa sistuämnda med livarandra - cller Mycenans; hos de lïgst stående, eller Rnssulerua, den liögsha bland dessa typer, Amanitans; hos Lactarierna, som intaga medlersta platsen af de tre, ir det ock den medlersta af de tre andrá, som förekommer, eller Collybinus.

Vi bedja fâ eriura derom, att dessa anmärkningar icke härflyta från en blott subjektiv, och derföre lït vilseledd, upplattning. Ordningsföljden Amanita - Collybia - Mycena kan ej ens underkastas ivist; ej heller ordningsföljden: $\boldsymbol{H}_{\boldsymbol{y}}$ grophorus, Lactarius, Russula; likasâ litet påståendet, att de former i dessa slägten, som uttrychia Clitocybernas typ, stá 
lıögst; eller det factum, att de lïgre formerna i sistnämnda trenne sliggten ultryclia de förstnämndas typer, detta, såsom vi anfört, i onvänd ordningsföljıl, jemförd med samma förstniimndas egen.

Till stöd för vâra påstáenden, isynnerhet $\mathrm{i}$ sistnämnda hänseende, der vi tro ensimt våra bilagors intyg bindande, åberopa vi de teckningar vi lemnat (pá Tablo. I och II) af ofvan anförda typer. Vi mảste blolt belilaga, att vi uraktlåtit der upptaga nảgon bland de bögst stående IIygrophori.

IIvad som af allt detta mest öfverraskade oss, var, såvil att hos ett sả lågt slående slägle, som Ihussula är, en typ slulle finnas, om ock blott delvis, uttryckt, hvilken tillhör de lıögst af alla stâende; som ock, och ännu mer, af alla de öfriga grupperna bland Ayaricinei, - och dessa äro ganska mánga, sâsom en blick på vår sehematiska framställning af Hymenomycetes ảdagaligger - alt ingen finnes, utom Russula, som eger lameller, if alldeles lika form med den hos Amaniterna vanliga; eller hatt, af så stora dimensioner, som $\boldsymbol{A}$ maniter's och lkussulers, hvilken ̈̈ir i kanten strimmad, såsom ofta ïr fallet hos dem.

Vi hade anmärlit detta förhållande (hvilliet för öfrigt vid en jemförelse lïll faller $\mathrm{i}$ ögat) utan att, genom någon annan, våı uppmärlisimhet derpå blifvit líistad. Först efteråt, då vi gerna ville se, om nâgon annan fistat sig vid detta samma förhållande, som öfverraskat oss, eftersiogo vi hvad Fries anfört om Rissule i sitt Systema Mycologicum Vol. 1; hvilket föröfrigt högst utmärlita arbele vi, i systematislit hänseende, sällan brubat anlita, då vi egt all häri följa det isynnerhet $\mathrm{i}$ delta afseende innu langt mera utmärlita arbetet af samma lörfatlare: Epicrisis Syst. Myeol.

I förstnämnda arbete hade vi emellertid tilltredsställelsen finna nyssnämuda förhảllande anmärkt. Det heter der nemligen (p. ̈̈4) om Russule: "Fungi . . inter avelatos cum Amaniti, prima velatopun tribu, analogi."

Vi voro omstïndliga $i$ anställande af alla dessa jemförel. ser, liliasom vi varit ull'̈̈rliga $i$ deras framstillning; men vigten af den idé, i fall den var sann, som då manade oss att 
noga betralita alla förhållanden, luvilka med denna idé liunde slå $\mathrm{i}$ något sammanhang, ålïgger oss un ïfven någon ulförlighet i framstälningen. Vi hitéa sa mycket mera till denna utförlighet liänt oss uppfordrade, som vi sednare vid undersölning af samma idés giltighet iifven med afseende påa andra lirelsar, öfverallt, der tillriiclilig kiinnedom on de enskilda förhållandena medgifvit oss möjligheten af en undersölning, funnit dess sanning. En stor del af livad vi anfört förckommer ock redan $i$ vår förnt nämnda af'handling, likasom der ock bevis finnas lemnade för flera af våra gjorda påståenden, i fall, der sâdana här salinas; livarföre vi i sådana hä̈nseenden få till densamma hänvisa, likasom vi redan förut gijort det $\mathrm{i}$ några vissa, sïrskildt uppgifna.

Betriffiande den grupp af slïgten, som utgöres af $/ / y$ grophorus, Lacturins och Russula, och livilka vi trolt oss finna intaga medlersta platsen af den något mer omfattande lirets, hvillien sjelf åter vi funnit skïl anse för en central lirets i IIymenomyceternas familj, hade vi sålunda laft tillfälle i tvenne hänseenden göra den anmärliningen: att denna lirets företedde ett inverteradt förhállande, emot det som vi varit vana finna gällande för öfriga liretsar i samma familj.

'Till de mångfildiga beröringspunkter vi funnit slïgtet Lactarius ega ât alla håll inom Hymenomyceternas familj, funno vi slutligen tvenne, omedelbara, $i$ den utmïrkta analogie, som, ehuru i till en del olika af'seenden, det visar till tvenne stora firan livarandra vidt skiljda grupper eller sliggten, Clitocybe (subgenus under Agaricus) saml Lentinus. Rörande detaljerna hïrat hänvisa till vår ofvan anförda afhandling.

Vid den granslining vi anstiillt, lutruvida, såsom vid det första närmare betraktandet förefallit oss, Lactariorna verkligen utgjorde ett centrum bland IIymenomycetes, hade vi sålunda, i mångfaldiga hänseenden funnit denna vår hypothes beliräiftad.

Idén var dock så ny och så fristáende, jemförd med allt hvad vi hade oss bekant, rörande af andra gjorda bestämningar af centra i naturliga grupper, att vi andock kïnde oss 
långt ifrản tillfredsställda; sả vidt vi nu $e j, i$ en bindande analogie, genom uppolingande af tillvaron af ett lilia tydligt tipriagladt centrum i nagon annan lirels, som, efter allt hvad vi lunnit, Laclarierna voro det bland Hymenomyceles, kunde för vâr hypoihes finna ett afgörande vitsord.

Väl hade vi funnit allt lala lör, att sliggtet Cortinurius utgjorde ett tylligt centrum i ordningen Agaricinei (jfr vår ofvan anförda afhandling), men vi behöfle elt kraftigare stöd; det var blott $i$ vissheten om tillvaron af elt centrum $i$ en atminstone lika omfallande, eiler bältre en ännu större, krets ä Iymenomycetes sjelliva utgöra, som vi ansågo oss liunna finna della.

Ingenting låg dâ närmare, än att till Svamparnas klass i sin helhet vïula vâr blick

Ilvilar vår öfvertygelse, tänkte vi då, på fast grund, när vi anse Lactarierna verliligen ugöra elt centrum bland $\boldsymbol{I}_{\boldsymbol{y}}$ menomycetes, så bjuder den analogie, som öfverallt råder $\mathrm{i}$ naluren, att det centrum, som dả bör finnas i Svamparnas lilass, bör till denna stå $\mathrm{i}$ ett lika förhállande med det, hvari slïgtet Lacturius stâr till Hymenomycetes.

Detta förhállande var emellertid ej uttömdt blott dermed, att detla sliggte visade beröringspunliter, nïstiun uleslutande genom analogier, ât flera sidor inom liretsen, ïn nagot annat sligte $i$ densamma gjorde, ulan vi hade derjemte funnit, att, bland Hymenomycetes, slïgtet Lactarius framför alla utmärlite sig genom en mảngfald af egendomligheter, till en del särdeles framstảende, hvilla gjorde det liiltare ïn något annat slägte, att genast vid första aublicken igenlïuna.

Gil'ves derlöre ett slägte, anmärlkte vi, som utgör ett tydligt utprägladt centrum i Svamparnas klass, då bör detta, genom utmärlita egendomligheter, vara innu mera framstånde och, bland alla i hela klassen innelattade slägten, vara ännn lïttare alt vid första anblicken igenliänna, än slïglet Lactarius sjellt; alldenstund detta, såsom atesiutande liaraliteristiskt för IIymenomygcetes, bör vara underordnạdt den högre enḥ̣t som sölies. 
Gifves nu - friggade vi oss - i svamparnas lilass ett sligte, genom egendomliga liaraliterer ännu mera ufmärlit och vid första anblicken ïnnu lättare alt igenlänna, ̈̈n slägtet Lactarius?

Utan tvifvel - muste vi genast svara os. - ïr slägtet Phallus elt sadant.

Motsvarar nu detta slizgte de beslimningar vi fistat vid begreppet centrum, méd afseende pá svamparuas hela lilass?

Stor var Författarens bestörtning vid slienet af den bländande klarhet, som nu, liksom omedelbart upptïnd, plötsligt upplyste ett förut dunkelt ämne, ett ïmne af största omfattning och betydelse. Till dess behandling hade hin, under ett ödmjukt söliande efter sanningen, af omständigheterna förts; ej förmätet gått åstad. Det var honom docli nu, som om lan hade utstrïickt handen för att hemla Prometheus-facklan och oncdelbart derefter funnit denna der hvilande. Genomtrïingd af sanningens frulitan, har han bäfvande med Linné utropat: "Deum omnipotentem a tergo vidi, transeuntem."

IIvad vi nu sâgo, det var en enliel och lilar, redan vid första anblicken bindande, anordning af alla familjerna i svamparnas klass till en harmonisli enhet. Denna bild hafva vi öfverflyttat på vår Tab. VII, och hoppas alt äfven för andra redan eft flygtigt ögonliast sliall vara nog för att inse, hurusom sliigtet Plialius, i den ena och samma representant af detsamma vi der afteclinat, sjelft utgörande höjdpunliten i den familj till lıvilken det hörer (Gasteromyceternas), på det mest utmiirlita sitt erbjuder slienet af höjdpunliterna i de tvenne andra familjer, Hymenomyceternas och Discomyceternas, hvilka, jemte Gasteromyceternas, utgöra de fullkomligaste af de sex lamiljer, af hvilka svamparuas klass bestảr. Med höjdpunkten i den fjerde, eller Pyrenomyceternas, erbjuder slägtet Phallus átminstone genom en af sina kända arter, en icke otydlig analogie. 
Vi förutsälta för öfrigl, för orduingen $\mathrm{i}$ vår schematiska eller bilulliga framstälning af dessa familjer, såsom riglig den sammanstillning af desamma i trenne serier - Lvarje serie beslácnde af en gymmocarpisli och en angiocarpisk afdelning - som vi, iastänmande $i$ en mundulig framstälnning i dolta hänseende som vi af Fries egde, med hans begifvande sliriftligen meddelat i inledningen. till vå "Syuopsis Fungorum Hydnaceoram in Suecia nascentium. P. I. Up. Is:35."

Enligt denna ordning maste Iymenomyceles och Gasteromyceles ulgöra den Cörsia scrien, Disco- och Pyrenomyceles den andra: de båda sistnïmonda med re föra i alseende på inbördes stälning analogir.

Om nu denföre ocli cj någon sa öfveraskande tydlig analogic råle emellan släget fohnllus sant de liullls fumna formerna från höjdpunliten af Pyrenomycetes - elurn sâsom vi anför en tillräcliligt tydlig fines - sâ är deremot hela familjen Gasteromycetes uppenbarligen analog med familjen Pyrenomycetes, ehnru den förra i graden ẩ fulllomlighet stảr vida öfver dea serluare.

Till stödjande al dessa grunder för våt påståcnde om slägtel Phalli centrala plats i svamparuas lilass liommer ännu en oustandighe!, livilken öliar det underbara i denna af oss upplagade tillvaro af ett fydligt utprägladt centrum.

Vi hafva, i början af denna afhandling anmärlit, att den inre byggnad, fill betydligg del af jemförelsevis stora, lalotrunda celler, som tilliommer sliggtena Lactarius oeh Russula, i Hymenomyceteras familj ä för dem egendomlig, och ej hos nigot annat slägte förelommande. Vid gransliningen af den inre byggnaden af Phallus impudicus, hafva vi funnit den del, som hos arterna af detta slägte utgör den största massan och med slial torde fä anses lör den mest utmärliande, dess stipes, byggrl af alldeles dylika lilotrunda eeller, som de, al hvillia Lactrrius och Lassiela lill så stor del utgöras.

Den sliblinad eger dock rum i den inre byggnadeu hos dessa tre slïgten, alt cellema hos Lactarius och Russula dels, siosom luos Russula, ligga mer eller mindre tät omslingrade af myclict fina filoriller, dels, sâsom vi oftast sett hos Lacta- 
rins, gruppvis, i lager af sålana inbäddade, under det på samma gang denna hyggnad här öfrerallt är genomvälil af, ujöllisaft förande, liarl; hos Phallus deremot äro cellerna fullkomligt fria frăn nagon annan slags vifuad vid sidan af, eller emellan sig.

Albildningar af cel!emas form och förhållanden hos dessa tre sliggten hafva vi meddelat (Tab. VHI).

Substansens art iir derjemte ock naggot olika: hos Phallus broslarlad (cartilaginea), hos de andra lös.

Det är sålunda endast med Phallus, som Lactarius och Russula såluula visa en tydlig analogie, för att ej sïga förvandlslaap - dessa båda bestämningar gå för öfrigt, såsom bekant är, $i$ naturen ej sällan öfver i hvarandra hvad den inre byggnaden angår.

Ofvermaskande var det derföre, alt till alla de andra berüringspunktertıa, åt skiljda siclo:, med höjdpunliterna af alla de liögre familjerna inom svamparnas klass, lıvilka Phallas erbjuder, finna denna med just sjelfva centrum bland de lögst af alla stående Hymenomycetes.

Enligt hvad flera, af andra lemnade, teckningar, liksom de yitre formernas förhảlanden, synas gifva vid handen, bestå sannolilit àtslilliga üliriga Gasteromycetes till störe eller mindre del af lilotrunda celler. Nigra techingar, som fullt tydligt ádagalägga elt sådant förhållande erinra vi oss cj hafva sell; ej heller förchommer $i$ vårt land någon representant af́ nágot af de underbara slägten, hvilka stá Phallus nära. Här torde ock vara lämpligt erinra om let förhållande, som vi ofvan anmärlit, att Lactarius och Russulu i formen af sina sporer med många Grasteromycetes ega en öfverensstämmelse, som, så vidt liändt är, de icke ega med nảgra slägten eller arter inom IIymenomyceternas tamilj.

Vi nämnde nyss, att flera märkliga slägten stå Phallus näıa. Äfven häri förekommer således ock en märlalig analogie emellan Phallus och Lactarius: aft det nemligen är med till omfånget små, men från hvarandra mycket afviliande slïgten, som de, hvardera i sin familj, bilda natorliga grupper, samt å andra sidan, att dessa från livarandra mycket afvikande 
slägten hafva det gemensant, alt lält limna skiljas från alla andra till familjen liörande. Detta förhállande synes gălla $i$ änm högre grad om gruppen Phulloidei, än om den vi laallat för den "centrala bland Mymenomyceles"; ly här är det lï̈nda antalet arter, som hörer under dess sliagten, gansla ringa. Erinras bör emellertid, alt dessal alla släglen halva silt egentliga hem $i$ de varma linderna, der hithörande vïxter jemförelsevis blifvit mycliet litet uppsökla.

$\mathrm{Vi}$ voro nu fast öfvertygate on tillsaron af ett eentrum för svamparnas hela lilass, likasom vi hïri vonnit det slöl vi tyckt oss hehöfva för vâr, för öfrigt med intel strilligga, förut vunna åsigt om tilkaron af elf eentrum bland Hymenomycetes.

Hit hade vi hunnit vid utarbetandet af inledningen till vår Monogradi öfver Lactorierua. (Med afscende pá átslilliga detaljer, hvilka vi här utelemnat, hänvisa vi áter lill denna). Vi harde derefter den tillfedsstälelsen höra Prof. Fries offentligen godkïnna văı ảsigt om Lactariernas centrala plats bland Itymenomycetes. Samma glidje blet oss dock icke besliärd fö̀" vårt påstående om det analoga förhållandet med slägtet Pluallus. Isynnerhet dock dá, nïr den förra satsen ïr antagen, förefiller oss den sednare evident. Dess sanning föreliom oss sâ inlysande, aů vi ej mer liunde tvifla.

Hanģathiga äro de resultater, till hvilka vi lommit genom savail närmare utveckling af denna vin upptïclit pâ det fiilt, der den nïrmast blifvit gjord - mycologiens - som genom att fullfölja den på vidt sliiljda fät inom den organislia naluren.

Vi tro oss hafva uppdigat tydligt ulpräglade centra, både för växtverlden, sảväl $\mathrm{i}$ dess helhet, som fö̀ många andra af dess provinser, ïn svamparna; och derjemte såväl för djurvertden $\mathrm{i}$ dess hethet, som för flera af dess provinser.

En följd häraf har varit, att vi selt oss i tillfille att såsom vi våga tro, icle ulan all framgảng - försöka en framstiilning at schematiska bilder af kretsarnas inbördes förhảilanden på de områden, der vi anställt våra forsliningar.

Vår schematiska framställning af Djurverlden kunna vi ej betrakta annorlunda, äin såsom ett mycket flygtigt utkast. 
Såväl isynnerhet vår eģen obetydliga erfarenhet rörande de otaliga enslildheterna, som möta pai letta fiilt, som äfven, om ock hiirmed jemförlt, i ringa mån, den loorta tid, livaröver vi egt att förfoga, hafva hjudit oss, att här iclie gå uböfver de första elementerna. Glade om vi sluble vinna det orlï̈nnande, afl åtminstone grundliniernas riglning icke iir 0 rätt aritydı, våga vi ubluedja oss benäget öfverseende för alla öfriga brister i denna lihl.

Pá vårt schema öfver Växtverldens laretsar våga vi lägga słörre vigt. Dels göra vi på defla fält ansprâli pra nảgot närmare heliantslap med enskildheterna, dels hafva vi pa ularbetandet af denna bild nedlagt lingt mera tid oeh mödi.

Var framstälning af liretsanas föhallanden $\mathrm{i}$ svamparnas hela lilass är angifien i blutt några enlila drag. För dlessas lïgen och förhallinden hoppas vi liunna redog̈̈ra, om vi ock mer än villigt erliainna, aft bilden förvisso bör en ggång lumna lemnas maingfildigt bältre. - Vi erinra dessulom deron, att alla vâra schenata lumna anses såsom - så vidt vi länna - - det första försöliet, att, efter noga faststiilda hufvudgrunder, symbolisht framställa den organislia verldens olilia liretsars lägen och förhållanden till hvarandra.

På vârt schema öfver Ifymenomycetes töras och måste vi lïgga den största viglen. Delta onfattar en jemförelsevis inslisăılat krets af naturföremål, och anordnandet af liretsarne pả denna bild lıafva vi liunnat och boedt - så snart vi en gång vågat försölet - byggga på en noggrannare lännedom af arterna. En jemförelsevis sâ beslaffid har ock stått oss till buds. Under många år hafva vi àt hit hörande växters studium egnat mycken tid och omsorg. De flesta arter af de icke så fả, hivilka vi antrïfat, hafva vi noggrant aftecknat samt utförligt beslirifvit. Delta gäller enellertid hufvudsalkligen rörande sådana arter, som ej låta sig lïngre tid förvaras; dessa utgöra dock flertalet al dem, som I vårt land föreliomma.

En synnerligen egen omständighet g̈ör ock en schematisk framsıällning af liretsarnas inbördes förhållanden bland dessa växter både lïttare att med någon större visshet lảngt in $i$ 
det enskilda ulföra, liksom, i jemförelse med en likartad bild ofver något annat omsåle, lällare alt pả motsvarande säıt upplatla. Med dessa växter eger nemligen det egendomliga förhallande rum, att, mäst formen på lymeniet, hvillen liatt i en mycliot enliel bild åskadliģ̋̈res, deras liännotecken till inbördes aiskiljande frin hvaranda väsendligen bestå $\mathrm{i}$ den yltre omlipetsens förhállandrng, samat $i$ beskaffenheten af den substans, af livillen de äro byggda. Isynnerhet $i$ lessa bâda sistnämma häusecuden låla sig deras hufvudtype myeket lät anlydas $i$ en schemalist framstalluing, pá säl vi genom den af oss lemmade hoppas ådagalagdt; om ock dessa typers lonturfigurer äro lemuale i myeket lörminskal skala.

Emedan emellertid det just ï i Hymenomycetemas familj, sum vi söka det närmaste heviset för det inom velenskapen, så vidt vi vela, nya vi ofvan framstillt, har det varit oss af särdeles vigt, att isynnerhet pá detta omrâle läzt limma meddela bevisen für våra påstảnden. Ehuru vi tro, atı vår ofvan nämnda schematistia framstailning, såsom folalbild betraklad, slall innelaalla det fömämsla af dessa, emedan den iclie obelydligt, sâsom vi hoppas, liubtar öfverhlicken öfver de allmännare dragen af lägen och förhâllanden emellan familjens liretsar, äro deremot de på schemat lemade fignrema för små, alt medlela någon tyollig fioreställning on åtshilliga detaljer, på lıvilla vi cchsá måst Jägğa viģt.

Vi hafva derföre af ofvannimnda anledning anselt tjenligt pá särslidua abeller medilela i naturlig storlek vilürda liontur-teclningar af alla de typer, vi pâ schemat lemnat i förminskad sliala. Väl sliulle vi i slället lumnat hänvisa till i redan hefintliga figurverli öfver de högre svamparna meddelade tecliningar; men dels äro dessa arbeten $i$ råt land fögra spridda, dels finnes ej heller bland dessa något, som upptager typerna på nảgra bỉad sá fullständigt samlade som det var vår afsigt alt meddela eller som vi till en del utfört. linapp lillgång på tid nörgade oss att till baittre tillfille uppslijuta medidelandet af de två tabeller, som böra omfatta ty. perna för de lägre ordningarna i familjen. 
Vid affattandet for örigt af schemala sjelfva har let gålt oss så, alt då della arbete var afslutadt nu blott högst ringa tid ståt oss ăler till sammanfattande all dessa blad. Vi hafva måst finna oss i denna hårda nödvändighet. Icke så alldeles obelydligt med material ega vi hopsamiad till ett utförligare słödjande af våra påstånden.

Det förnäinsta stödet för dessa, vi upprepa det, söka vi dock i vâra schemala, likasom vi à andra sidan anse deras lillvaro, ifall, åtuinstone hvad lufvuddragen angåa, de grrunder, hvarpå de hvila, äro righligá, sảsom det häsła resullatet af våra forskningar. Att med all den omsorg, som stod i vår förmåga, utarbeta dessa schemata, har derförc nåst vara vår förnämsla uppgilt; hurn påkostande för öfrigt den nödvändighet är lıvari vi un befiuna oss.

I största kurthet gá vi derföre nu alt pedogöra för det som vi anse uigüra det hufvudsakligaste af innelållet $i$ vảra schemala.

Vi hafva antagit, om man ville sölia genom en bild för sig askiadliggöra Vaixt- och Djurverdens ställning till hvarandra, at detha lampligast kume slie genom tecknadet af ivenne linier, som med livarandra bilda en vinkel; dermed antylande, hurnsom dessa tvenne den organislia naturens stora kretsar med sina lighre former med hvarandra convergera, med sina liögre divergera.

Beslämningen "högre" och "lägre" former innebär vidare, alt dessa båda linier, $i$ någon mån ålminstone, böra, ifrån den punkt der de sammantriffa, hafva en rilutuing uppàt.

Hura stor den absolua latningen af dessa linier emot horizonfal-planet bör länkas vara, derulll länna vi ingen beslämoningsgrund.

För bedömandet deremot af den-relativa, af linierna eunot hvarandra, våga vi tro, att fürhállanden inom de olika serier, som de hvar för sig förestalla, lemna en loflig ledning.

Emedan Djurverldens högsta former, ulan mindsla frảga, i absolut mening mâste förlklaras på naturalstrens sliala intąga en långt högre plats än V̈̈xtverldens högsta, bör vara klart, att den öfre andpunkten af den linea, som föreställer Djur- 
verldens serie, bör stả myeliet lögre, äı den öfre pả den, som förestïller Växtverldens.

1 huru mycket lägre plan bör då ändpunliten ligga af den linea, som beteclnar Vïxtverlden? - var vår nästa fråga.

Vi tro åter, att gil!iga gruuder fiunas för anlagandet, att deu bör ligga $\mathrm{i}$ ett plan, som ungefärligen motsvarar det, Lvari de högsta stråldjurens förestiilles vara

Grunderna härför anse vi vara, först i allmänhet, aft hufvudformen för dessa djur är densamma, som finnes uttryckt i de lı̈̈gre växterna, lipans- eller strálformen.

Vidare: att en anmärliningsvärd analogie råder $i$ de talförhaillanden, luvilka äro typiskal, å ena sidan för de olika addehningarua $\mathrm{i}$. stráldjurens krets och a den andra för afdelningarna inom väixtverlden.

Fyrtalet herrskar bland de lïgre stråldjuren och bland de kryptogama vïixterna. Femtalet hos de högsta stråldjuren och de högsta växterna.

Sex- eller Tretalet hos de former, som i bâda kretsarna intaga medlersta platsen.

Sedan man en gång gifvit den ena linien någon, inom en viss gräins, vilkorlig rigtning, då bör den andra liniens af den lörras vara beroende. Vi sigga: "inom en viss gräns"; ty'ingendera linien lian fả ģå vinkelrält upp ifrản horizontalplanet. Deita sluble innebära, att naggondena seriens former i ett enda räll uppstigande plan sammanhöra, lägre med lı̈gre.

Inom raturalhistorien är det deremot allmiint erliändt, att naturföremålen visa sig sammanhöra i mångfaldiga liretsar, hvilka hvar för sig hafva sina höjdpunkter; men dessa kunna i allmänhet omöjligen omedelbart sammanstäHlas med de lägsla $\mathrm{i}$ en annan lirets.

Bảda seriernas linier mâste derföre föreställas lulande emot horizontal-planet, för att bereda möjlighet till angifvande, hurusom de enskilda seriernas eller liretsarnas höjdpunkter förelomma, hvar för sigg, såsọm oftast ïr fallet, firistaende.

Elementer för att närmare uppmäta lutningen af de stora linicr eller plan, Lvillia böra beteckna Vïxt- och Djurverldens 
enheter, tro vi kunna erhållas genom ett noggrannt uppmätande af förhållandena på enskilda liretsars plan.

Vi anföra såsom exempel vårt schema öfver Hymenomycetes. Med den röda linie, livilien, i brutna delar liorsar det plan, Lvarpå de mindre liretsarna äro förlagda, hafva vi velat beteckna horizontal-planet, eller planet för lika värden. Inom samma parallela linier på detta schema hafva vi förlagt analoga former, sâsom Clitocybe, Lactarius, Lentiuns. Den förstnämnda typen är oneliligen att anse såsom fullkomligare ïn den sistnämndiı; derlöre lafva vi låtit de linier, som omsluta deras kretsar, liliasom alla linierna i schemat, hafva en lutande stälning emot horizontal-planet. Lactarius samt Difformes, en bland Agarici grupper, hafva vi antagit slå ungefïr lika högt, och derföre ställt dem i sanma horizontalplan, angifvet genom den röda linien.

Så myckel vi än häıvid saknat fullt bindande objekliva grunder för detla $\mathrm{i}$ detalj gående bestämmande af lika eller olika vïrde - vi erlänna det villigt - våga vi dock tro, att retenskapens framtida utveckling sliall medföra många sådana, livilla vi ïnnu sakna.

Om så sliulle vara, då vore ock härmed möjligheten gifven till ett noggrannare bestämmande, först af planernas lutning för de enslilda liretsarna, och genom sammanställning al många af dem, för hufvudplanerna; likasom omvändt man i de sednares sannolika lutning egde elementer för corrigerandet af fel vid bestimmande af de förras.

I afsaknad af dylika fasta grunder hafva vi mảst nöja oss med mera godtycliga. Vi upprepa dock, att denna godtycklighet ej gerna liunnat gå öfver en viss gräns. Så t. ex. tro vi vara tydligt, att f. ex. gruppen Penduli i slägtet $A$ garicus obestridligen måste anses stå lägre än slägtet Lactarius, och att vi således ej kunnat fá förlägga dessa båda i samma plan, utan ställa de förra lïgre än de sednare.

Inom slägtet Aguricus är för öfrigt hufvudtypernas ordningsföljd, åtminstone der det är fråga om en och samma serie, alluför tydlig $\mathrm{i}$ de flesta fall, för att man skall kunna 
derom misstaga sig. Vi åberopa oss på förlıállandet med serien Leucospori i slägtet Agaricus.

Efter of vanstaende grunder lıafva vi bestämt planernas lutning. Sedan denna en gâng är gifven för ett af dem, bör af demna de öfrigas med större eller mindre sannolikhet liunna berïlinas.

För att nu säirskildt fïsta oss vid vârt schema öfver $H y$ menomycetes hafva vi låtit den första och den sista af de fyra större ordningarna inom familjen med sina liggre former convergera emot hvarandra, sedan vi en gaing hade gifvet, att centrum' i familjen utgjordes af slïgtet Lactarius. Försöket, modifieradt $\mathrm{i}$ enskilda förhållanden, har, såsom vi våga tro, utfillit lyckligt.

A naloga former äro ställda inom samma parallela linier; affina under hvarandra $i$ samma serie.

Vid slïgtet Ayaricus sım eger flera serier, livilla med sina lïgsta former nära sammanhöra, med de högsta äro sliiljda, hafva vi frågat oss: livar slulle elt centrum i detla sliggte sökas? Vi hafva trott att detta obestridligen måste vara ibland Myporrhodii. Vi halva da på försök stält linien för denne $i$ vinkelrät rigtning emot horizontalplanet, och tro oss ifven genom della försöli lyckats rigtigt angifva flera förhiollanden.

Slizgtet olvaria, som ugör höjdpunliten i denna serie, stâr i midten mellan Amanita och Coprinus. Sedan vi stält dessa båda pai livar sin sida i lika al'stand frán Volvaria, hafva de minitre liretsar, hvillais slallning af dessa båda höjdpunkter ir beroende, fätt det läge på större cller mindre affstånd från hvarandra, som mycliet vïl motsvarar deras närmare eller fjermare förvandtskap till hvarandra.

Genom olika färger hafva vi betecknat olika substans, ehnru vi af många slicil, $i$ detta afseende $\mathrm{j}$ liunnat gai långt i det ensliilda.

Efter ofvan anförda grunder hafva vi förfarit vid angifvande af seriernas riggtning, såväl på öfriga delar af detta schema, som på tvenne af de öfriga schemata*). och IX.

*) Tab. VII får sin fürlilaring genom en jemfürande blick på Tabb. VI 
En följd, hland andra, af den öfversigt vår schemaliska framstiillning af Iymenomyeetes lenuar tro vi vara, alt, redan vid en flyglig blick på detsamma, det bör vara lalart, att gruppen Coprimus icke kan såsom särskildt slägte fả skiljas frản slïgtet Ayaricns. Sker detta, så utbrytes en slutsten $\mathrm{i}$ den vackra byggnad, som sliigtet Agaricus annars $\mathrm{i}$ i systematiskt häısecende företer.

\section{Vi öfvergå un til! Tab. VIII.}

Efter samma grunder, som vi uppsölite centrun i svamparnas likass, sölite vi ock elt centrum i Vïxtriket. .

Hvilka äro då de, som hland alla vïxter genom egendomlig liarakter äro mest utmärlita och framståcude, samt lättast alt igenkämna?

Vi erinrade oss omedelbart Linnés ord: "Palnæe sunt speetatissima vegetabilia, ideoque vocavi Principes."

Vi höllo oss tills vidare vid dessa, samt frågade: utgöra nu Palmerna den grupp i vïxtriket, som företräilesvis har beröriugspunkten ât alla sidor.

Vi hafva trott oss kumna besvara denna frảga med ja!

Att börja med fả vi då eriora, att vi $i$ de aldra flesta hufvućpunkter antaga för det saunaste af alla hittills framstiillda växt-systemer det af Fries lemnade, lufvudsaliligen sådant detta är ordnadt i v. Dïbens "Handbok öfver Växtrikets Naturliga familjer."

En viglig förändring vilja vi dock dervid göra, nemligen att med siöd af många förfitlares yrkanden ställa Coniferte och Cycadere lägre in alla öfriga phanerogama växter.

Ait det åter ïr $\mathrm{i}$ särdeles mannga och vigtiga hänseenden som Cycadere träfla tillsammans med Filices torde vara af många författare tillräckligt antydt. Schnitzlein erinrar uck (Iconogr. fam. natur. regni veget.) hurusom Cycadere, enligt flerfaldiga nyare undersöliningar, utgöra en verklig mellanform emellan Coniferce och Filices. Sâsom elt appendix under Consferce ställa vi, i likhet med flera författare, Casuarinece och Equisetacece. 
Af dessa samtliga tre klasser bilda vi en egen provins, hvilken vi förłägga nedanom Monocotyledonere.

I de flesta öfriga hänseenden inslïnma vi $i$ ofvan anförda anordning af Växtrikets Familjer, några enskildheter af mindre vigt oafsedda.

I samstïmmighet med de fordringar vi uppställt på ett centrum visar sig nu, att Palmerna, hvillia tillhöra Monocotyledonerna, och bland dessa infaga en låg plats, befinna sig ungefär lika långt aflïgsna från ytterligheterna, de höğsta så vail som de lïgsta tormerna. Vidare torde ingen växtfamilj finnas, hvillien såvïl lörbinder de lägre växterna med de högre, som Palmerna göra. Vi hatva erinrat, hurusom vi anscetl nödigt, ställa săväl Coniferce som Cycadece på en plats nedanom Monocotyledonerna. Bland många andra skäl berïltigar ock deras uppträdande under de äldre vegetalionsperioderna till denna anorduing. Med Cycadce åter, likasom ifven med Filices visa nu Palmerna, hvad den inre organisationen angår en nära förvandtskap. "Gehen wir auf die Organisation der Palmen ein, so finden wir in ihren vegetativen Organen durchaus den Typus der Farne und der $C_{y-}$ cadeen", yttrar Sehleiden *).

llvad àter deras ställning i Monocolyledonernas egen provins angår har någon anmärkt, att sammanfattningen af deras naturliga liänneterken visar dem såsom en sluten formserie, livilken visar blott ringa likheter och förvandtskaper med andra ${ }^{* *}$ ). Vi torde fă erinra, att detta är ett alldeles likartadt förhållande med det vi haft anledning anmärka rörande Lactarius och Phallus, alt de vid första anblicken visat sig stå liksom alldeles isolerade, under det de lileväl vid närmare granskning visat sig hafva isynnerhet analogier åt många håll. Vi tro att förhållandet ock är detsamma med Palmerna. Det är àt särdeles många sidor inom Monocotyledonernas provins, som man funnit jemförelsepunliter med Palmerna bland Graminea, Juncacere samt flera af de små i dessas närhet ställda familjer, såsom Liliacese och andra,

*) Ilandbuch der Medicinisch-plarmacentiscen Bolayik, Juni 1852, p. 144.

-) Schnialein I, c. 
Med ledning al livad vi hittills funnit, torde vi nu kunna, hypothetiskt, sảsom nigonting tillhörande centra, tillägga: att de àro myckel naturliga grupper, eller slutna formserier, hvilka vid första anhlicken synas stá liksom isolerade.

I sammanhang härmed torde vi få anföra några ord af $\boldsymbol{D} e$ cuisne *) med anledning af det af honom uppställda slägtet $\boldsymbol{L} \boldsymbol{e}$ pinia bland Apocynea: "En efret, les genres les plus curieux d'une fimille sont ceux qui forment la liaison d'un groupe anx groupes voisins, et qui, participant a la fois de chacun d'eux, conservent certains caractères essentiels à la famille à laquelle ils appartiennent, en même temps qui'ils offrent des anomalies qui masquent à la prémière vue Jeurs réritables rapports."

Det har lör oss varit af intresse att få anföra detta yltrande af en utmärkt författare. Hurusom hans beskrifning af sådana slägten, som utgöra föreningshandet emellan till hvarandra gränsande liretsar, nästan fullständigt sammanfaller med vår bestämning af samma begrepp, torde af sig sjelft vara inlysande.

Vi hafva anfört, all vi i loufvudsak anslutit oss till det af Fries framställda System af Växtrikets Naturliga Familjer. De förändringar vi i vår schematiska bild gjorl, äro, ulom hvad vi ofvan anfört, att vi ställt bufvudkretsarne eller provinserna, ej under hvarandira, utan vid sidan af livarandra, anordnat serierna med afsecude pá centra, samt stält det hela i elt lutande plan.

Grunddragen af Fries' system äro, i sådana fall der skiljaktighet råler emellan författarne: antagandet, med nỉgra fürändringar, af De Candolles indelning af Dicolyledonerna; tillerkännandel, med Jussieu, af hög betycletse för systematiken af blomkronans hypogyna, perigyna eller amphigyna stälning; inom de, på grund liäraf, bildade serierna ett närmare bestämmande af kretsarnas lägre eller högre plats till vãsendllig del pả gr'und af fruktens byggnal, och derigenom anordnande af krelsarna i analoga serier; samı fastställandet af Composilæe alt vara de fullkomligaste växter. Genom fastställandet af centra samt tecknabde, med ledning häraf, af den schematiska hild vi lemnat (Tab. VIII), hoppas vi, att

*) I Annales des sciences naturelles 1849, troisième série Tome 2, p. 193. 
Fries' systenı, sảlunda utveckladt, skall visa sig lösa mảnga svárigheter, i växteruas anordning.

Ōiver otillräckligheten af en lineel anordning torde för öfrigt väl icke gerna kumna vara skiljda åsigter. Liıdley beklagar sig deröfver ofta. Linnés yttrande är bekant: "Plantæ utrinque affinitatem monstrant, nti territorium in mappa geographica." Gieseke, Batsch hafva sökt teckna dylika schemata, som del vi fiamstältt, öfver växtverlden; Berkeley och Harvey ölver svampars och alger's förvandtskaper inom sig — dessa sistnämnda lock i aldra enklaste utkast.

För angifvande af störe eller mindre art-antal inom en krets, genom tecknaudet af en större eller mindre yta, àheropa vi Linnés föredöne, i hans Philos. Botanica; der lıan sålunda betecknat klasserna $\mathrm{i}$ sitt sexual-system.

Vi fästa uppmärksamleten derpå, hurusom: genom vảr anordning af de öfriga serierna pá hvar sin sida om den serie, den vi anse central bland Dicotyledonece: Caryophyllinee, Portulacacere och Oleracee komma livarandra nycket nära, under det på samma gång åskådliggöras de förvandtskaper samma kretsar hafva äfven àt andra håll, hvar och en för sig i olika rigtning.

Genom den plats kretsen Parietales pả vảrt schema följdrigtigt erhåller, lemnas skäl, å ena sidan för förfaltarmes förenande af Thalamiflore och Calyciflorce till en lirets, å den andra för Fries's åtskiljande af desamma sásom egna kretsar.

Anordnandet pả en yta af familjerna medgifver att åskảdliggöra, hurusom en del former kunna stå mycket lågt, men ändock ega förvandta bland lı̈gt utbildade. Exempel: Haloragere.

En anmärkning mả här inskjutas rörande elt förhàllande, hvilket dock nära af sig sjelft bör vara inlysande. Pà várt schema nemligen, dả vi dermed till en början ej kunna sträcka vảra ansprảk längıe, än att söka fastställa grundlinierna för växternas an- 
ordning, halva vi hvarken kunnat företaga ett arbete $\mathrm{i}$ alia hithörande detaljer - för hvilket för öfrigt inga krafter kunna förslá, redan af det skäl att fullständigt inventarium på jordens växtskatter äunu pii mycket lingt uär ej är upprätlarlt, för att ej villröra några flera - ej lieller hafva vi, för det afsedda anndamålets sliuld, önskat gå längr'e i detalj än vi gjort. Vi hafva derföre väl följt Fries' anorduing af familjerua, men upplagit de nảgot större kretsar Endliçher uppstält sảsom de närmaste utöfver familjerna. Blott der, siosom vid Haioragere, inom en gilven lirets af förvandta, gradskillnaden i fullkomlighet äı alltör stor emellan olika delar af densamma, hafva vi åter i flera upplöst de af Endlicher bildade. Det är för öfrigt icke rörandle legränsuingen af de kiretsar, under hvilka familjerna närmast sammanfatlas, som författarne hysa så särdeles olika ảsigter. Sả mycket mera skiljaliliga deremot ăro åsigterna röranłe grunddragen för samma kretsars anorilning.

Grunden, hvarföre vi anse lineen för Fries' Fauciflorce sisom eentral bland Dicotyledonere är, all vi, med Lindley, antaga den hithörande "Nyrtal Alliance" Lindl., inom sig innefatta den lilla, men i alla häuseenden högst utnärkta, familjeı Napoleonere. Oı́ denna fanıilj gäller alla de bestämningar vi uppställt såsom utmärliande elt centrum. Hos denna familj hafva författarne àt de mest skiljda håll velat finna förvandtskaper, eller uppvisat likhet - med Campamlacere, Nymphreacere, Cucurbitacee, Passiflorere, Symplocacere, Rhizophorere. Den mest öfverraskande hland dem alla torde vara den, hvarå $R$. Brown fastat uppmärksamlıet, vid den, shisom en ö långl ute i occanen, närnıast dock intill Dicotyledomeres continent, jemte sina förvandta belägna Raffiesia. För askỉdliggörandel af denna likhet hafve vi meddelat, enligi Schnizlein, figurer i genomsnill af representanter för bålla dessa familjer.

Enligt samma grunder tro vi oss kunna pảstå, alt Campanulinere utgöra centrum bland Corolliflorre, Ramneulacere bland Thalamiflore, Legmminose bland Calyciflore. - Vidare Cactere bland Funciflore, Malvacere bland Colmmiflore, Enphorbiacere bland Centriflora, samt tillsvidare, innan vi kunna erbjuda andra 
skitl, - hufvudsakligen för analogiens skulı - Asclepiadere bland Tubiflore.

Alt Scitaminere utgöra centrum bland Fructiflore, sant att denna serie är en högst utmärkt, torde haddadera vara $\mathrm{i}$ ögonen fallanile.

Vi fästa derefter uppuärksambeten derpå, hurusom dessa, livar lör sig och oberoende af de andra bestämda, centra, sins emellan visa utmärkta analogier.

Vi hafva förut erinrat, hurusom ett dylikt förhitllande af analogie eger rum emellan Lactarins och Phatlus. - Vil en blick pả te nu af oss framställda centra bland Dicotyledonece visar sig, att Cactere ega utmärkt analogie med Asclepiadere och Euphorbiacere, för de mảnga succulenta former dessa familjer innehảlla; de biala sednare lör ölrigt sins emellan genom sin märkvärdiga ölverensstämmelse i egenskaper *) oeh sin mjöllsaft; genom sistnämnte egenskiap ảter Asclepiadere merl Campammlinere. Vidare komma ock, enligt författarnes erinringar, Euphorbiacere mycket nära intill en afdelning (Büttneriacere) bland Malvacere.

Till öfriga analogier som Palmerna visa, torde äfven fả räknas den som ofvannämnda Scilamiere erbjuda genom sima fjädernerviga blad.

Vi hafva på vårt schema betecknat Alger och Svampar genom Ivenne lutande planer, hvilka korsa hivarandra. All Lafvarna, hvilka af alla författare ställıs mycket nãı till ıle egentliga Algerna, vid sidan al dessa synas böra intaga en plats lägre än de högstas och högre än de lägstas bland dessa, torde lätt medgifvas. Hvad som derjemte är oförnekligt är den särdeles utmärktı analogie $\boldsymbol{L}$ afvarma erhjuda med Discomycetes bland Svamparna. Del är derföre ungelärligen viłl deras miđt, som vi látit nämula planer beröra hivarandı.

Uppenbart är derjemte, att Svamparna med sina högsta former tydligen velta ảt djurverlden - qväfvehalt, yttre gestalt, m. m. - samt att genom sina lägsta Algerna med densamma äro på det närmaste förbundna. Genom sina lägsta former deremot gränsa

*) V. Düben I. c. p. 56. 
Svamparne intill sjukliga bildningar på de högre växternas blad, genom sina högsta former Algerna åter - lendens till bladbildning - till de högre växterna $i$ allmänhet.

På grund af omojligheten att med en absolut karakter omfatta och beteckna den af oss dock sảsom en ganska naturlig krets uppställda sammanfattningen af Coniferce - jemte ditlörande med Cycadere och Filices, hafva vi, särskildt med stöd af ett dylikt förfaringssätt inom Zoologien, benämnt denna krets efter det organ, som hos densamma är företrädesvis ulhilładt, nemligen stanmen. För konserquensens skuld hafva vi benämnt de öfriga af de fyra liögre växtverlıens provinser efter samma grundsats, och tro alt dessa namn äro sanna uttryck af förhillanderna. Vi bedja emellertid alt vår bestänningr med afseende på dessa namn sả màtte tydas, att vi f. ex. ause först bland Dicotyledonex fruktformerna uppträla $i$ all sin mi̊ngfald, under det vi dock helt visst antaga, att älven, såväl hvad, hlad, som stanı och blonmor angår, de fullkomligaste formerna här förekomma.

Största öfverraskningen och den starkaste hekräftelsen, såsom vi tro, för sanningen af vår theorie om centra $i$ allmänhet, sádan vi varit i tillfälle uppställa den med ledning af vår erfarenhet rörande nảgra af vextrikets kretsar, har mött oss, dả vi tillsett huruvilla - livad den analogie, som öfverallt genomgàr naturen, bjöd, ifall vảr theori var sann - centra äfven finnas inom djurverldens kretsar. Vi hafva liärvid holt lästat oss vid förhållandet först rörande djurriket i dess helhet, och derefter vid de tvenne högsta provinserna i detsanma, rörande bvilkas naturliga begränsning inga delade tankar finnas. Resultaterna böra vara så mycket mera bindande, som de kretsar äıo omfatlande och nalurligt begrãnsade, lıvilka vi granskat.

Vogi, i sina "Zoologische Briefe", indelar Djurverlden i 2:ne stora kretsar: Den högre, hos hvars former i ägget alltid fiunes en motsats emellan embryo och äggegula; samt den lägle, hos hvilken hela äggegulan uppgår i embryot. 
Sásom ett hihang till dessa kretsar, af författarne med ett gemensamt namn kallade Zoa, komma Zoidierna, hos hvilka ägghildning ej eger runt.

Under den högre kretsen bland Zoa falla animalia vertebrata och articulata samt Cephalopoderna; under den lägre de öfriga.

Nu är häremot afgjordt, att, såsom utbildade djur, Cephalopoderna mycket nära sammanhöra med Gastropoda samt i allmänhet med Animalia Mollusca (Cormozoa).

Såsom embryoner sanmanhöra sảlunda Cephalopoderna med de högre djuren, sảsom utbildade med de: lägre.

Här har naturen sålunda utbildat former, hvillia $i$ en enhet på en gång representera den högre och den lägre hemispharen af djurriket. De utgöra ock en krets, som viıl första anhlicken stà liksom isolerad.

Derjemte visar det sig, att de hafva förvandtskaper eller analogier åt le, frảı hvaraudra, nıest allägsna och skiljda håll. Ibland Zoidierna förekonma, inom kretsen Polylhalamia, former, med hvilka en del Cephalopoder så nära öfverensstämma i utseende, att de lörra länge af flera författare förenats med $\boldsymbol{C e}$ phalop. On dessas nära förvandtskap med öfriga Mollusca hafva vi ofvan ytlrat oss. Med de högre djuren visa de många likheter: Vi anföra härom följande yttranden af Carpenter: "in the class of Cephaloda, especially in the Dibranchiate order, we meet with a condition of the circulating apparatus, which manifestly etablishes the transition between that of the Mollusca in general, aud that which is peculiar to Fishes"*) samt: "Here (hos Cephalopoderna) therefore, we find sketched - out, as it were, the complicated form of the vascular system in warm - blooded animals possessed of a complete double circulation." **)

Utom i dessa hänseenden, hvarigenom Cephalopoderna när'ma sig de högre djuren, förtjena älven anföras: det inre skelettet (hos Belemniterna) samt deras särdeles högt utbildade ögon.

Att de äro genom en mångfald af egendomliga karakterer utmärkta och framstående, derpả finnas mảnga intyg: loäcksaften;

*) Principles of comparative Physiologie, Ed. 4. p. $253 . * *$ ) I. c. p, 254. 
afskiljandet hos en del hannar af en af armarna till bildande af en sjelfständig individ — en aflägsen analogie, genom bildandet af nya indiviler genon delning, med de lägsta djuren; deras besynnerliga utseende.

Till Vertebraterna słả Ormarna i alldeles samıma förhảlande, som Cephalopoderna till djurvelden i allmänhet.

De vertehrerade djuren indelas, enligt Gould, Agasitz et Perthy, enligt embryots beskaffenhet, i en högre krets och en lägree. Till den högre höra, på grund häraf, Dägglljur, Foglar och Reptilier, hvilka hafva embryoner med Anınion och Allantois; till den lägre Amfibier och Fiskar, hvilkas embryoner sakna Ammion och Allantois. Om nu ock Ormarra, likasonı Cephalon. i sin krets, sảsom embryoner tillıöra den högre afdelningen, konıma de derenıt genom hela sin sednare utveckling mycket nära Amfibierna, och intaga i sin lirets sålında alldeles samma plats, som Cephalopoderna i sin, eller den centrala.

Bland Leddjuren utgöra, enligt Författarnes intyg, Arachnida den krets, som bildar föreningsbandet emellan Insekter à ena sidan och Myriapoder samt Crustaceer à den andra.

Om Ormarna liksom Arachnida gäller, att de i sina kretsar, hvar för sig, utmärka sig genom en mångfald egendomliga karakterer.

On Ormar och Spindlar gäller, att de i sitt giftiga bett sins emellan visa analogie.

Om benägen rättelse anhålles för några betydligare tryckfel, som râkat qvarstå på sidd. 27 och 28 :

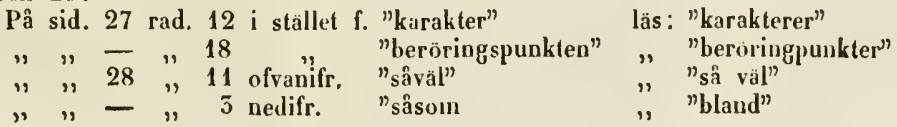





\section{tra}

\section{6:

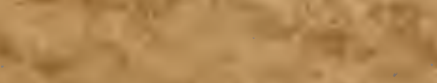

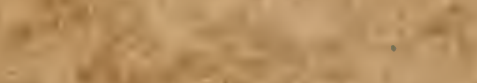

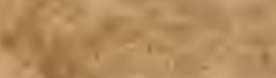

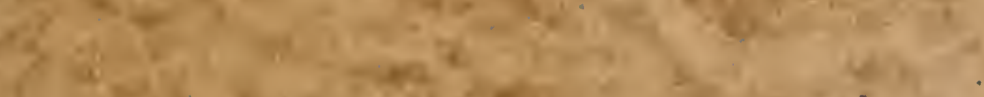

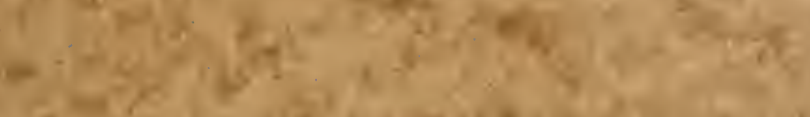

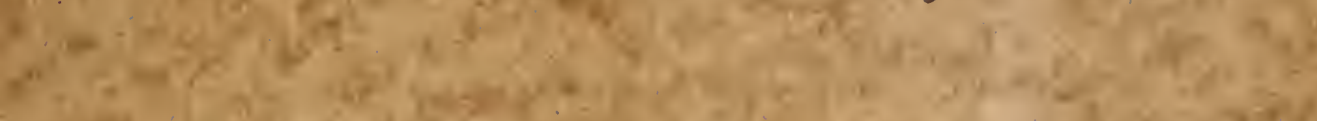

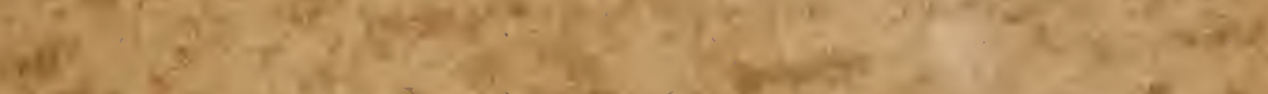

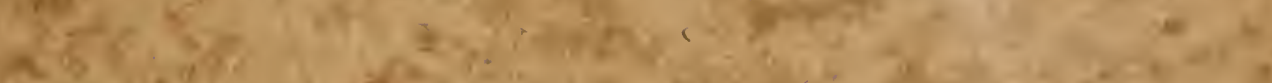

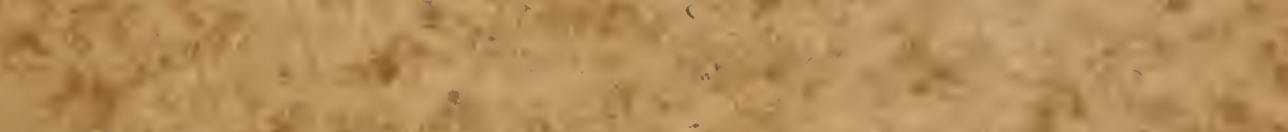

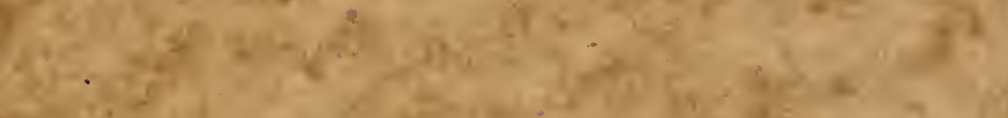

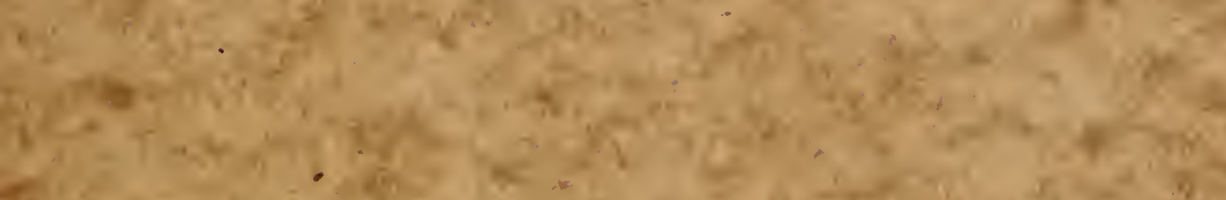

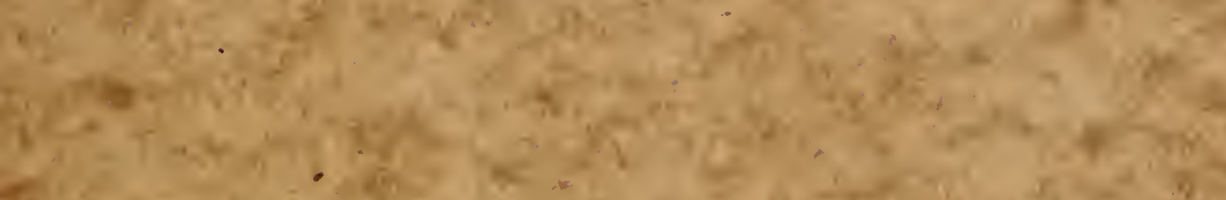

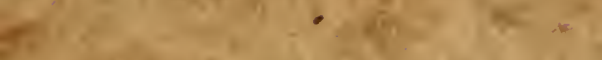

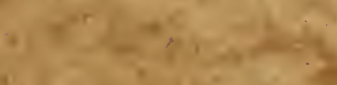

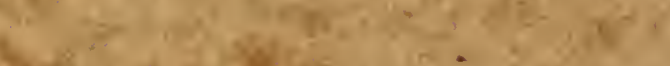

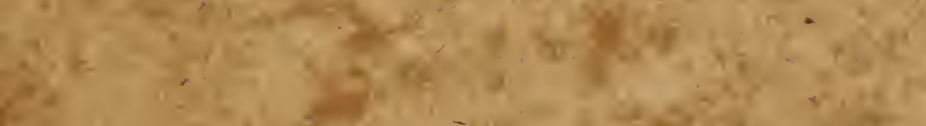

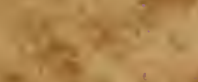

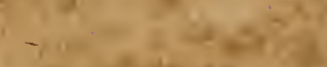

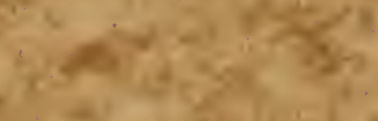

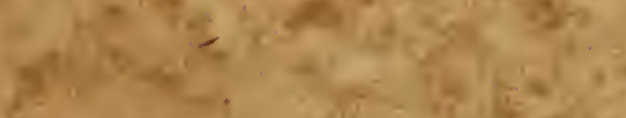

\section{(}

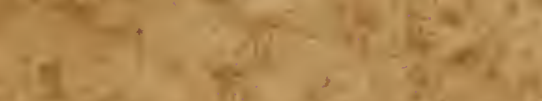

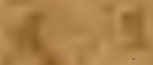

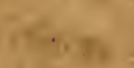

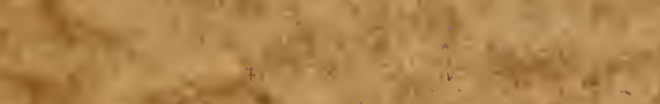

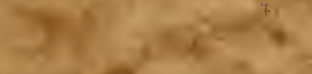

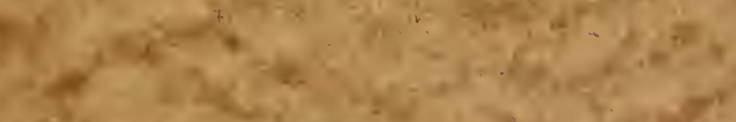

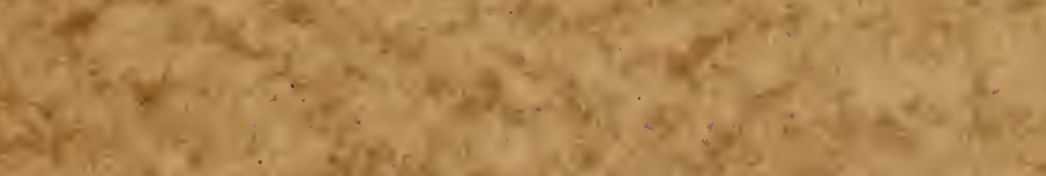

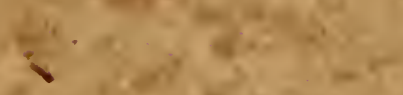
21

21 . 


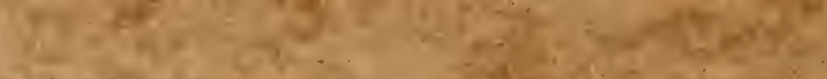

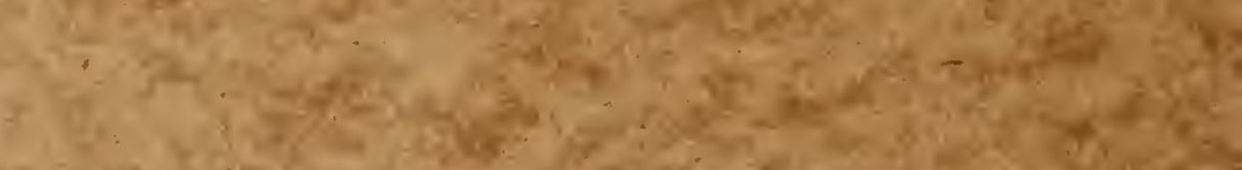

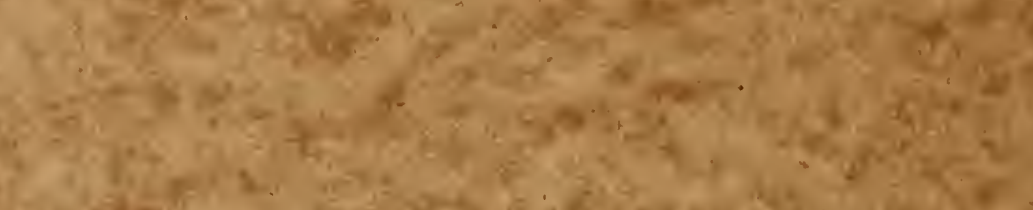

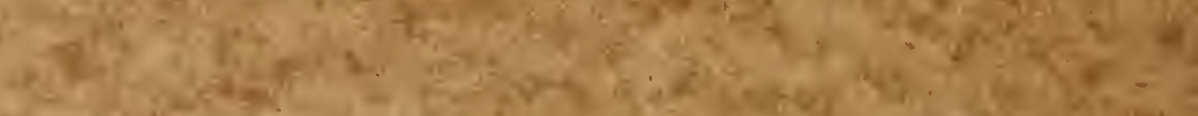

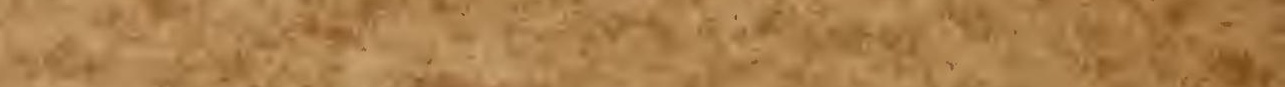

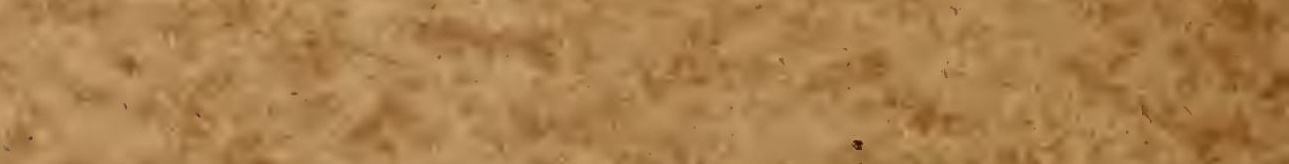

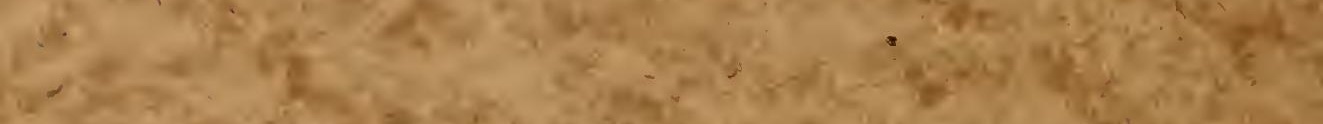

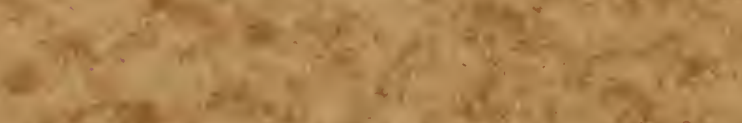

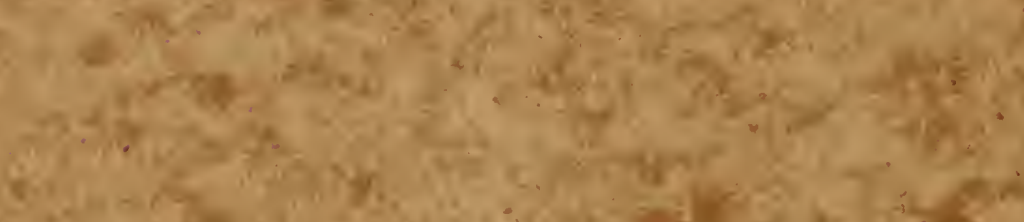

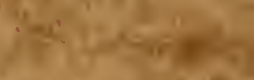
\%

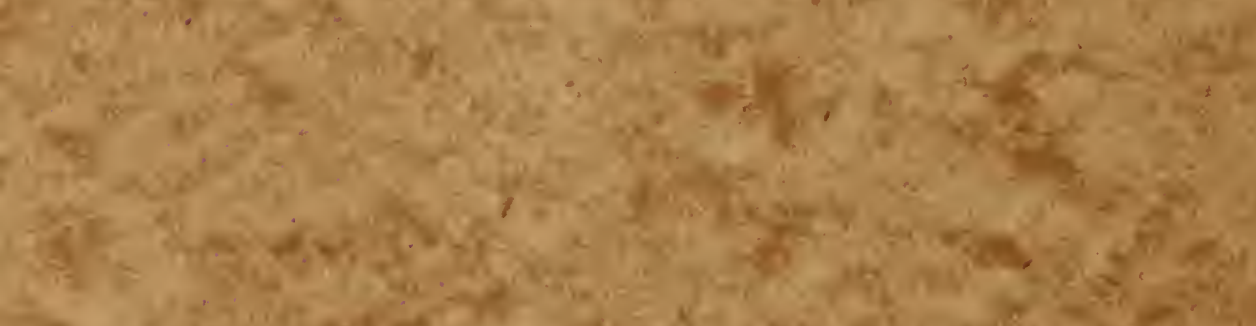

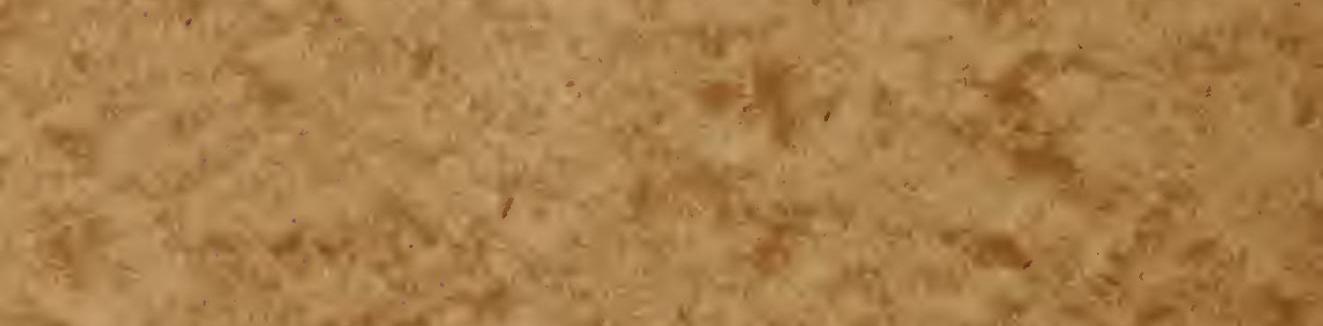

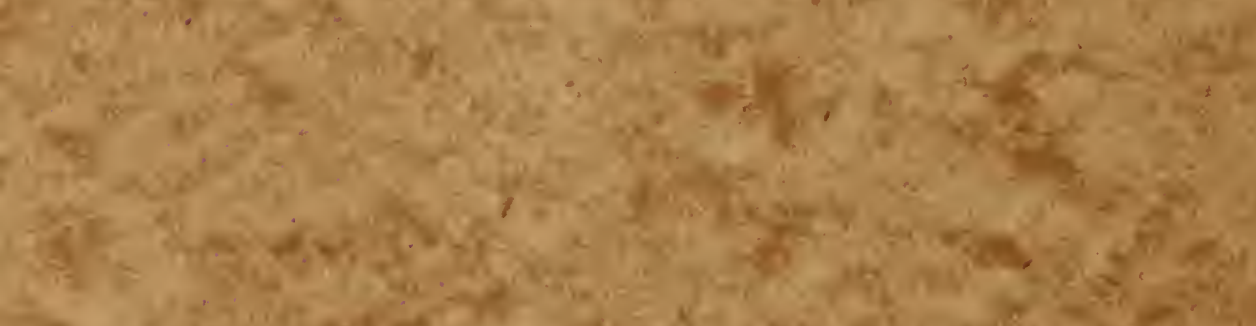

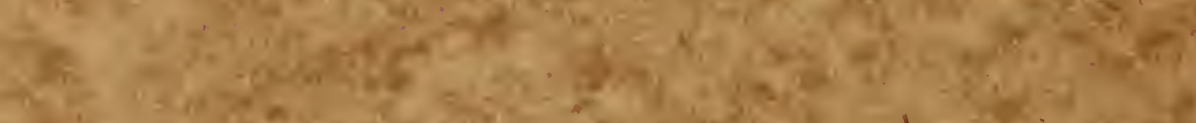

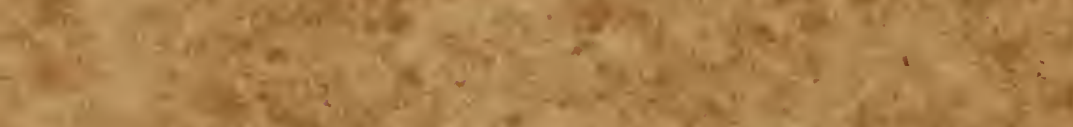




\section{Lindblad, Matts Ado/Om tillvaron af ett \\ || || || || || || || || |||' || || || || || || || |||||||||

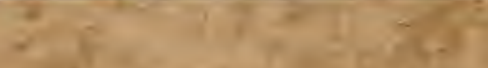




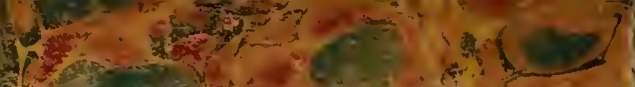

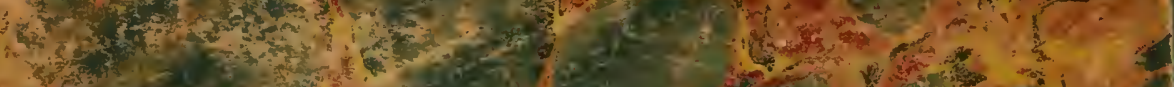

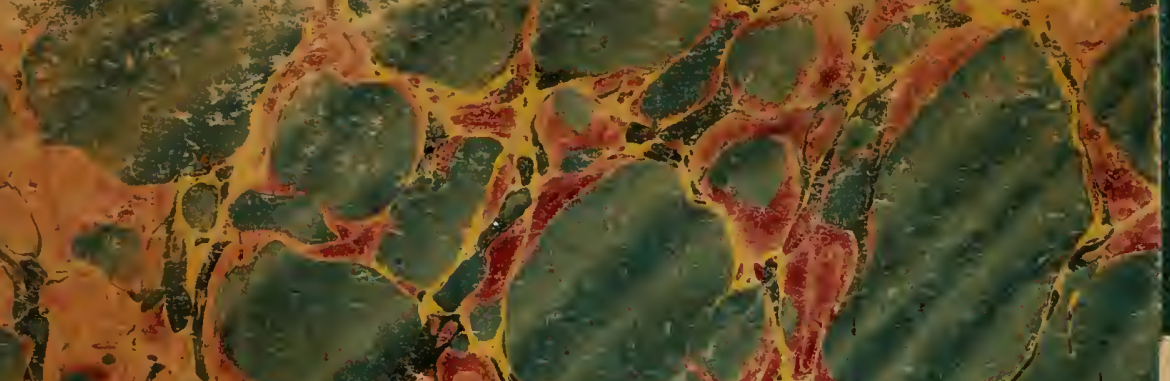

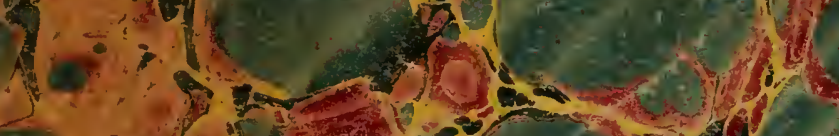

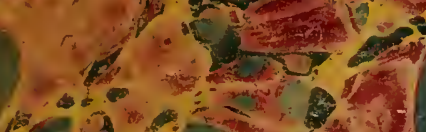
is

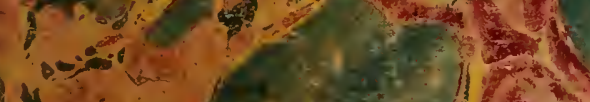

(n)

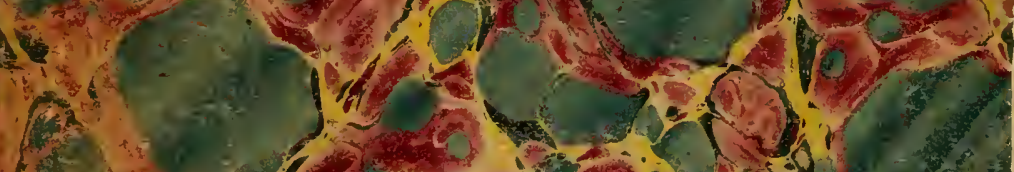

t.

(it)

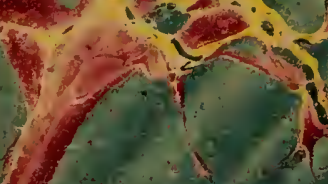

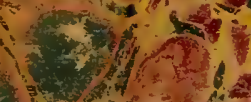

18

(x)

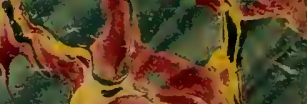

20

(1) 